\title{
Working
}

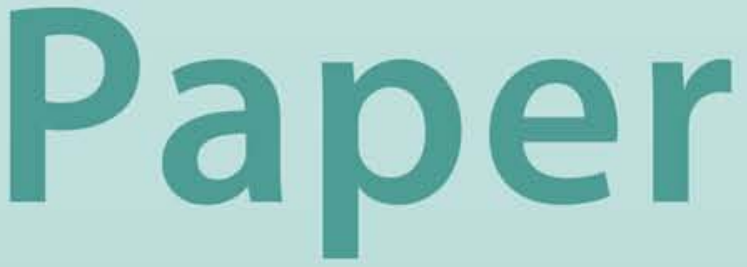


The Global Credit Crunch and Foreign Banks' Lending to Emerging Markets: Why Did Latin America Fare Better?

Herman Kamil and Kulwant Rai 


\title{
IMF Working Paper
}

\section{Western Hemisphere Department \\ The Global Credit Crunch and Foreign Banks' Lending to Emerging Markets: Why Did Latin America Fare Better?}

\author{
Prepared by Herman Kamil and Kulwant Rai ${ }^{1}$ \\ Authorized for distribution by Steve Phillips
}

April 2010

\section{This Working Paper should not be reported as representing the views of the IMF.} The views expressed in this Working Paper are those of the author(s) and do not necessarily represent those of the IMF or IMF policy. Working Papers describe research in progress by the authors and are published to elicit comments and to further debate.

\begin{abstract}
The recent global financial turmoil raised questions about the stability of foreign banks' financing to emerging market countries. While foreign banks ${ }^{6}$ lending growth to most emerging market regions contracted sharply, lending to Latin America and the Caribbean (LAC) was significantly more resilient. Analyzing detailed BIS data on global banks' lending to LAC countries - whether extended directly by their headquarters abroad or by their local affiliates in host countries - we show that the propagation of the global credit crunch was significantly more muted in countries where most of foreign banks' lending was channeled in domestic currency. We also show that foreign banks' involvement in LAC has differed in fundamental ways from that in other regions, with most of their lending to LAC conducted by their local subsidiaries, denominated in domestic currency and funded from a domestic deposit base. These characteristics help explain why LAC has not been struck as hard as other emerging markets by the global deleveraging and pullback in foreign banks' lending.
\end{abstract}

JEL Classification Numbers:F34; F36; F37.

Keywords: Banks; global: credit crunch; cross-border lending Authors‘E-Mail Address:hkamil@,imf.org; kr9c@virginia.edu

\footnotetext{
${ }^{1}$ Herman Kamil is an economist at the Western Hemisphere Department, International Monetary Fund, and Kulwant Rai is a PhD student at University of Virginia. The authors are grateful to Sebastian Goerlich for his help in interpreting the data from the Bank for International Settlements, and to Marcos Chamon, Kai Guo, Cesar Serra, Hui Tong and especially Steve Phillips for comments on earlier drafts. Patricia Attix provided excellent editorial assistance. We also thank participants at the XIV LACEA Meetings, the XIV Meeting of the Central Bank Researchers Network of the Americas, the IV FLAR International Conference, the XXIV Central Bank of Uruguay Economic Conference, the IDB's Research Department seminar and the IMF's Western Hemisphere Department seminar. Preliminary results were disseminated in the Spring 2009 edition of the IMF Regional Economic Outlook for the Western Hemisphere.
} 
I. Introduction

II. Data and Stylized Facts for Latin America ................................................................. $\underline{5}$

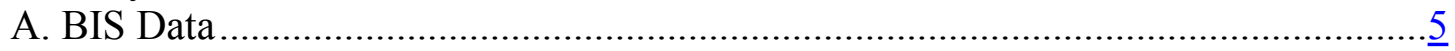

B. Key Features of Foreign Banks` Involvement in LAC ..........................................

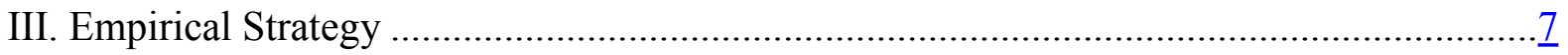

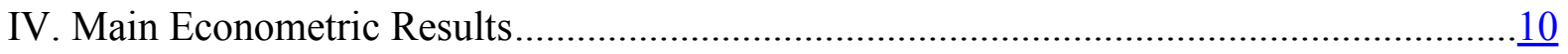

V. Was There a Retrenchment Post-Lehman? Latest Cross-Regional Evidence ................... $\underline{13}$

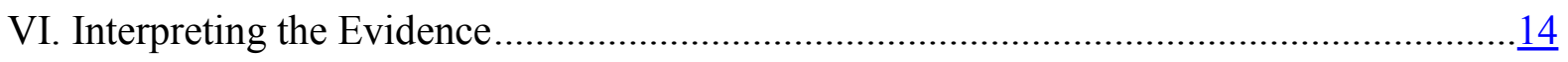

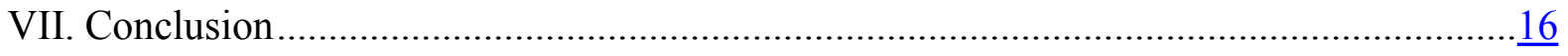

Tables

1. Foreign Banks' Lending to LAC: Developments as of end-June 2009.............................19

2. Determinants of Foreign Banks' Lending to Latin America .........................................

Figures

1. Share of Banking Assets Held in Subsidiaries or Branches of Global Foreign Banks ........21

2. Foreign Banks' Lending as a Share of GDP, 2008 ......................................................21

3. Share of Foreign Banks' Lending Extended through their Local Affiliates, 2008 ..............22

4. Deposit-to-Loan Ratios in Foreign-Owned Local Affiliates, 2007 ................................22

5. Foreign Banks' Cross-Border Lending to Banking Sector in Emerging Markets, 2008 ....... 23

6. Share of Foreign Banks' Lending Denominated in Local Currency, 2008 …....................

7. Total Foreign Banks' Lending in Foreign Currency in Emerging Markets........................24

8. Foreign Lending by Bank Nationality .......................................................................24

9. Growth in Foreign Banks' Lending, by Region ......................................................... 25

10. Change in Foreign Banks' Total Outstanding Claims since Lehman Demise, by Region. 25

11. Channels of Foreign Banks' Lending to LAC: Differences in their Behavior...................26

12. Spanish Banks Compared to U.S. Banks in Terms of Lending to LAC ..........................26

13. Total Foreign Banks' Lending to LAC Region ............................................................ $\frac{27}{28}$

14. Three-Month Money Market Spreads........................................................................ $\frac{28}{28}$

15. Financial Stress of Global Banks in Advanced Countries ...........................................28

16. Reported Tightening in U.S. Banks' Lending Standards ............................................29

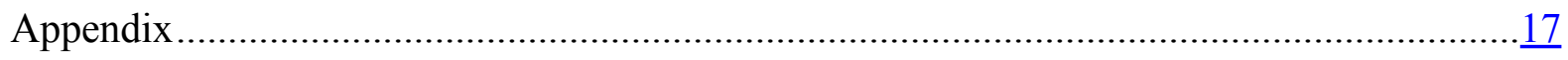

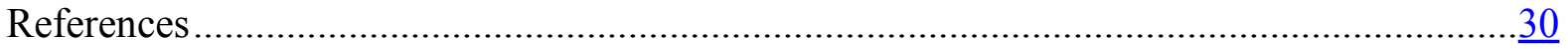




\section{INTRODUCTION}

Lending by foreign banks to emerging markets is a defining feature of financial globalization. In the years preceding the recent global crisis, foreign bank lending to emerging economies expanded rapidly — whether directly from foreign banks ${ }^{6}$ headquarters (cross border) or through affiliates operating in host countries. Although it had its pros and cons, on balance the presence of foreign-owned banks was generally believed to have enhanced competition and aided overall financial stability. ${ }^{2}$

During the recent global credit crunch, however, foreign banks were potential vehicles for spreading a crisis that originated in advanced economies into emerging markets. As their financial health deteriorated sharply, banks' global scramble for dollar liquidity and the need to deleverage balance sheets raised concerns that these bank flows could retrench significantly, disrupting macroeconomic stability in emerging markets.

For many Latin America and Caribbean (LAC) countries, the onset of the global credit crunch was a potentially crucial development. Over the previous five years, lending by foreign banks had become a significant source of funding for households and corporations in many economies of the region. Understanding how the global financial shock has been transmitted to LAC through the foreign bank-lending channel is therefore of policy interest not only for those countries that already rely heavily on foreign banks, but also for those that may be thinking of opening up their markets to foreign banks' operations.

In this paper, we undertake an econometric analysis of the determinants of foreign banks ${ }^{6}$ lending to the LAC region between the last quarter of 1999 and the fourth quarter of $2008 .^{3}$ We assess the effects of three key factors that have shaped the recent global financial turmoil - tight inter-bank liquidity, mounting pressure on major banks ' capital positions in advanced economies and more restrictive lending standards in developed countries' banking systems.

Our results indicate that, on average, international money market conditions have a significant impact on foreign banks' lending to Latin America and the Caribbean. In particular, funding pressure caused by liquidity shortages in the global inter-bank market adversely affects foreign banks' lending growth to the region. Also, a deterioration of parent banks' own financial soundness in advanced economies leads to reductions in their

\footnotetext{
${ }^{2}$ The presence of foreign banks has typically been considered a positive development in emerging market countries by strengthening risk management and corporate governance in host countries (through more efficient allocation of capital, increased competition, and more sophisticated financial services, among others). See Peek and Rosengren (2000), Claessens, Demirgüç-Kunt, and Huizinga (2001), Galindo, Micco, and Powell (2004) and Moreno and Villar (2005) for additional discussion on the costs and benefits of opening the domestic banking sector to foreign competition.

${ }^{3}$ In the paper, we use the following convention: - thin America" refers to the geographical area of South America, Central America and Mexico, while references to -th Caribbean" are standard. The region" or $-\mathrm{AC}$ " is used to refer to the full Western Hemisphere excluding Canada and the United States.
} 
financing to the LAC region. Changes in banks' lending standards in advanced economies also seem to have a statistically significant effect on the growth of foreign banks' credit to Latin America. Yet crucially, our results also indicate that the propagation of these global financial shocks is significantly more muted for countries where foreign banks conduct a higher share of their lending in domestic currency.

We also show that the nature of the involvement of foreign banks in LAC has differed in fundamental ways from that seen in other regions, notably Emerging Europe. Foreign banks conduct a higher share of their lending in the LAC region through local affiliates, which appears to reduce the risk of a homeward flow of foreign banks ${ }^{6}$ assets. In addition, much of the funding of foreign-owned subsidiaries in Latin America has come from domestic sources, i.e., from an expanding deposit base, rather than from parent banks ${ }^{6}$ resources (or from wholesale funding). This reduces the vulnerability to a sudden withdrawal of short-term external funding. Moreover, global banks with the largest presences in LAC markets have low exposures to emerging Europe, so that Latin America is not likely to be susceptible to a credit pull-back similar to, or feeding off, strains in emerging Europe. Together, these features of foreign banks' operations in the LAC region reduced the extent of contagion from the international liquidity squeeze.

The most recent BIS banking data available through 2009Q2 is consistent with our findings and interpretation. We show that following the Lehman demise in the third quarter of 2008, lending by foreign banks to the LAC region slowed rapidly, amid the freezing of global money markets and doubts about the health of banks in advanced economies. Most of this deceleration in foreign banks' total credit growth, however, reflected a sharp contraction in cross-border loans to LAC, which are largely denominated in foreign currency and funded in wholesale markets. On the other hand, lending by local affiliates of foreign banks - which is mostly denominated in local currency and funded with domestic deposits - proved much more resilient and continued to expand, even amid the global turmoil. Because such claims by local affiliates represent almost 70 percent of all foreign banks' claims on the LAC region, total foreign banks' lending to LAC actually increased slightly between 2008Q3 and 2009Q2 (when measured at constant exchange rates). This contrasts markedly with the behavior of foreign banks' claims in emerging Europe, emerging Asia and Africa and Middle East, which declined over the same period.

Overall, our results suggest that global banks can indeed act as a channel through which financial problems in advanced economies get transmitted to LAC economies- but also that the extent of such transmission and associated risks depends importantly on the nature of foreign banks' involvement, and this can vary greatly across countries. Thus, when evaluating the desirability and potential risks of allowing (more) foreign bank participation in their economies, policymakers in Latin America and the Caribbean may want to pay attention to multinational banks ' varying strategies of cross-border lending activity vis-a-vis direct entry into local banking markets, as well as the funding sources and financial autonomy granted to foreign-owned affiliates operating in host countries. 


\section{DATA AND STYLIZED FACTS FOR LATIN AMERICA}

\section{A. BIS Data}

In this paper we draw extensively on the consolidated international banking statistics reported by the Bank for International Settlements (BIS), which contains country-level information on the gross claims of foreign banks to the financial and non-financial sectors in Latin American countries. ${ }^{4}$ The reported claims include not only bank loans, but also other forms of financing through debt securities and equities; for ease of exposition, we will refer to all these forms together as - leding."

At the outset, it is essential to highlight that foreign banks extend credit to LAC (and other economies) through two distinct routes:

- Directly, from their headquarters abroad (overseas lending by parent banks or -ross-border flows"). In the terminology of a country's external balance of payments, credit received from a foreign bank through this traditional route represents a capital inflow, and the accumulation of a liability to non-residents (i.e., form of external debt).

- Indirectly, via the activities of their local affiliate banks in host countries (foreignowned subsidiaries or branches). ${ }^{5}$ Since the affiliates are residents of their host countries, the credit they extend locally does not, in itself, represent a balance of payments inflow or an external debt of the host country. For most LAC countries, this indirect route is the dominant form of foreign banks' involvement, and is often significant in scale. Indeed, these foreign-owned local affiliates now hold a substantial portion of local banking system assets in a number of LAC countries. ${ }^{6}$

An important advantage of BIS data is that it tracks banking systems' consolidated foreign claims worldwide, i.e., netting out intra-group positions with their affiliates worldwide; hence providing a comprehensive view of a global bank's exposure to a given country. ${ }^{7}$ This ownership-based viewpoint is especially of interest to the extent that global banks

\footnotetext{
${ }^{4}$ Foreign banks belong to more than 20, primarily OECD, countries (referred to as BIS-reporting countries"). In practice, there can be important distinctions between -fireign" and BIS-reporting" banks, especially in Central America where regionally operating, non-BIS-reporting banks are common. For ease of exposition, however, in this paper we refer to BIS-reporting banks as international, global, or foreign banks.

${ }^{5}$ Local affiliates include foreign-owned banks established in the host country (subsidiaries) and the agencies of the home country operating abroad (branches).

${ }^{6}$ However, in a few countries in the region (such as Dominican Republic, Ecuador, Guatemala and Venezuela), the banking system is largely domestically owned.

${ }^{7}$ McGuire and Wooldridge (2005) provide detailed discussion on the structure of the BIS consolidated banking statistics.
} 
choose to manage their holdings centrally, treating local affiliates as part of a global portfolio. For example, a global bank facing capital or liquidity shortages may instruct its affiliates to curtail their local lending to help improve the group's consolidated capital asset position, or to transfer liquidity to headquarters. On the other hand, even if some decisions are taken centrally, it is possible that local affiliates follow a distinct business model and that their local lending activities may respond differently — or not at all - to shocks affecting their parent bank. ${ }^{8}$ As will be seen, we find strong evidence for the LAC region of such differences in behavior in the most recent period of global financial distress.

\section{B. Key Features of Foreign Banks' Involvement in LAC}

Since 2005, foreign banks' lending to LAC has expanded rapidly, representing a significant source of funding for companies and households, and accounting for a significant share of banking activity in many countries by end-2008 (Figure 1). As a share of GDP, foreign banks' total claims are most important in Chile, followed by Costa Rica and Mexico, although they are significantly below the median ratio for countries in emerging Europe, for example (see Figure 2). ${ }^{9}$

In Latin America, two-thirds of all foreign banks' lending in 2008 was disbursed through local affiliates. This share is significantly higher than the median in emerging Europe (50 percent), emerging Asia (37 percent), and Africa and the Middle East (19 percent) as described in Figure 3. This reflects a steady shift in international banks ' business strategy towards LAC, from cross-border lending by bank's headquarters to lending through local affiliates. ${ }^{10}$

Lending by foreign banks' affiliates is mostly financed from domestic deposits, and their reliance on nondeposit funding (parent bank resources or wholesale financing) is particularly low in Ecuador, Argentina and Brazil as shown in Figure 4. This is in contrast to the situation in emerging Europe, where the flow of new credit in recent years has tended to be predominantly financed by cross-border flows from parent banks as illustrated in Figure 5. ${ }^{11}$ Reflecting the particular mix of local and cross-border lending,

\footnotetext{
${ }^{8}$ Cetorelli and Goldberg (2009) analyze the internal capital market transfers between globally-oriented US parent banks and their foreign affiliates in Latin America.

${ }^{9}$ In absolute size, Brazil, Mexico, and Chile accounted for almost 80 percent of all outstanding lending by foreign banks to LAC by end-2008.

${ }^{10}$ This shift in foreign banks` lending strategy was based, in part, in the acquisition by foreign-owned local affiliates of large local banks, with an already significant local deposit base. This has been particularly important, for example, in Peru, with the entry of Scotiabank (acquiring the third-largest bank on the system) and the reentry of Banco Santander (acquiring a medium-sized local bank) in the late 1990s. For a detailed account of foreign banks' mergers and acquisitions in the region, see Pozzolo (2008).

${ }^{11}$ Lending by foreign banks to the banking sector in LAC (as a share of total lending) is the lowest among all regions considered. For Asia and the Pacific, the proportion is almost 30 percent, while it is 15 percent for Latin America and the Caribbean.
}

(continued...) 
and the domestic sources of funding by local affiliates, LAC is the region with the highest share of domestic-currency-denominated lending in total foreign banks' lending. For most of the region's larger economies, half or more of all foreign banks financing is denominated in local currency, with this share exceeding 70 percent in the case of Mexico as detailed in Figure 6 and Figure 7. ${ }^{12}$

Banks from Spain and the United States are the dominant players in Latin America, jointly accounting for approximately 50 percent of all outstanding financing by foreign banks to Latin American and Caribbean countries. ${ }^{13}$ These foreign banks have low exposure to emerging Europe. ${ }^{14}$ Conversely, the most active global banks in emerging Europe (from Austria, Belgium, Sweden, and Italy), have a small presence in Latin America as illustrated in Figure 8. ${ }^{15}$

\section{EMPIRICAL STRATEGY}

To shed light on how the credit crunch has cascaded in Latin America, this section looks at the historical determinants of international bank lending to the region from 1999Q4 to 2008Q4, using a multivariate panel regression framework. ${ }^{16}$ The model is focused on analyzing the impact of the following three factors on foreign banks' lending activity to the region: (i) deteriorated global liquidity conditions, (ii) large write downs and weaker balance sheets of major international financial institutions, and (iii) the downturn in the lending cycle in advanced economies.

The baseline empirical analysis is based on a reduced-form model specification given by:

$$
\begin{gathered}
F B L_{i j t}=\beta_{0}+\beta_{1} \text { TED }_{t}+\beta_{2} \operatorname{EDF}_{t-1}+\beta_{3} L E N D S_{t-1}+\beta_{4} G \hat{D} P_{i t}+ \\
\beta_{5} \text { CRating }_{i t}+\beta_{5} \text { Deprec }_{i t}+\lambda_{t}+\gamma_{i j}+\varepsilon_{i t}
\end{gathered}
$$

\footnotetext{
12 See also Jara and Tovar (2008) and Caruana (2009) for an analysis of the currency structure of foreign banks' lending to LAC. Domestic financial dollarization is low in most of the large Latin American countries, and has been systematically declining in the more dollarized ones over the last decade.

${ }^{13}$ Canadian banks account for the largest share of foreign bank assets in the Caribbean. Foreign bank claims on Central America, on the other hand, are relatively diversified between U.S., U.K., and other western European banks.

${ }^{14}$ For a detailed analysis of international banks' exposure to emerging Europe, see Maechler and Ong (2009).

15 The exceptions are banks from Germany and France.

${ }^{16}$ Martinez-Peria, Powell and Vladkova-Hollar (2005) analyze annual changes in foreign banks“ claims on Latin American over the period 1985-2000. The authors, however, only focus on the foreign currencydenominated lending by foreign banks to the non-financial private sector in Latin America. Peek and Rosengren (2000), on the other hand, use BIS data to analyze how foreign banks reacted to crises affecting Argentina, Brazil and Mexico during the 1990s.
} 
where the dependent variable, $F B L$, is the quarterly growth rate in the stock of outstanding gross claims of foreign banking system $j$ on LAC country $i$ in quarter $t .{ }^{17}$ The sample combines 13 LAC borrower countries, and 14 non-LAC lender countries that report to the BIS (most of which are advanced economies) ${ }^{18}$ Figure 13 shows the evolution of total foreign banks' claims for a selected group of LAC economies.

The dependent variable covers direct cross-border lending by parent banks, and lending by foreign affiliates in each country, in domestic and foreign currency. It includes international banks' loans to banks in the host country that are not their subsidiaries/branches (such as loans, bank-to-bank credit lines, and trade-related credit) and loans to the non-financial sector. It also covers portfolio flows (such as holdings of securities) and equity shares in unrelated institutions (in particular, mergers and acquisitions, which are especially important for the region during the sample period).

Many growth rate observations of the dependent variable are extremely large, primarily due to countries entering or exiting the reporting population of banks, which can lead to sudden jumps in the outstanding stock of lending vis-à-vis particular countries. ${ }^{19}$ To address this, we exclude those observations were the dependent variable fell in the lower and upper 2 percent of the distribution in the sample. ${ }^{20}$

The explanatory variables used in the analysis are as follows ${ }^{21}$ :

- $\quad T E D$ is the spread between three-month U.S. dollar LIBOR and the three-month U.S. treasury bill rate (TED spread), and is meant to capture liquidity strains in global inter-bank markets (see Figure 14).

\footnotetext{
${ }^{17}$ The dependent variable is "gross" only in the sense that we do not consider changes in the liabilities of foreign banks vis-à-vis LAC countries. However, it is - at" in the sense that they include repayments of loans made by country $i$.

${ }^{18}$ The 13 LAC borrower countries included in the sample are: Argentina, Bolivia, Brazil, Chile, Colombia, Costa Rica, Dominican Republic, Ecuador, Mexico, Peru, Paraguay, Panama, Uruguay and Venezuela. They accounted for more than 95 percent of the outstanding foreign banks' lending in the region at the end of 2008. For the rest of the LAC countries not included in the sample, some of the explanatory variables were not available. We exclude from estimation those observations where a BIS-reporting lender country is from LAC (Brazil, Chile, Mexico and Panama).

${ }^{19}$ In addition, foreign banks' credit to smaller countries constitutes a very small share of total foreign credit, and thus tends to exhibit large variations over a small base.

${ }^{20}$ Excluding these observations, however, significantly reduces the regression fit of our model, since much of the overall variance in the dependent variable is contained in these observations. McGuire and Tarashev (2008) report similar findings.

${ }^{21}$ In the Appendix we provide more details on the definition and sources of the variables used.
} 
- $\quad E D F$ are market-based estimators of banks' expected default probabilities, constructed using data for publicly listed, globally active banks in each of the 14 BIS-reporting countries included in the analysis. ${ }^{22}$ In most countries, EDFs have showed a marked deterioration since September 2008, reflecting declining capitalization and earnings, and rising stock price volatilities of publicly-listed banks as shown in Figure 15.

- $\quad L E N D S$ captures changes in the lending cycle in advanced economies. It is defined as the percentage of senior loan officers who reported tightening in a given quarter, minus the percentage of officers who reported easing in credit standards to large and medium-sized firms in each lender country. The stiffening in borrowing terms in the U.S. banking system, for example, is illustrated in Figure 16.

- $\quad G \hat{D} P$ measures the percentage change in quarterly GDP in the LAC borrower country, which captures the buoyancy of economic activity in the borrowing country.

- $\quad$ CRating is a composite indicator of economic, political, and financial risks in each borrower country, to account for the fact that lower perceived economic and institutional risks tends to attract foreign bank investment. We use the International Country Risk Rating, published by the PRS Group. A higher value suggests better macroeconomic frameworks and institutions.

- $\quad$ Deprec is the percentage change in the borrower country nominal exchange rate against the U.S. dollar, to capture valuation effects (and possibly also portfolio reallocations that could occur in response to exchange rate movements). ${ }^{23}$

- The panel data estimation controls for fixed effects specific to each lenderborrower pair $\left(\gamma_{i j}\right)$, to account for time invariant and unobserved factors driving cross-country differences in foreign bank lending. ${ }^{24} \mathrm{We}$ also include quarter time dummies (for the first, second and third quarters of every year).

\footnotetext{
${ }^{22} E D F$ is the calculated probability that a bank defaults within the one-year (ahead) period, based on each bank's market value of assets, its volatility, and its capital structure. We employ data for almost 100 publicly listed banks which are globally active. We thank Patrick McGuire for making available the list of banks.

${ }^{23}$ BIS data are end-period values, expressed in U.S. dollars; changes in these values incorporate valuation changes (exchange rate changes, marking to market of securities, and write-downs of non-performing loans) and so may differ from net lending flows. Currency valuation effects can at times be significant, especially in countries where local currency-denominated lending represents a significant portion of the total.

${ }^{24}$ Foreign bank presence tends to be higher in countries with common language, similar legal systems and banking regulations, and geographical proximity (Claessens and Van Horen, 2008). For example, in Latin America and the Caribbean, 60 percent of foreign banks are headquartered in the United States and Spain,
}

(continued...) 


\section{MaIn ECONOMETRIC RESUlts}

The main findings are presented in the first column of Table 2. The estimated model provides a plausible explanation of the factors affecting lending by foreign banks to countries in Latin America. We find a significant link between global money market conditions and changes in international banks' lending to Latin America. Consistent with World Bank (2008) and McGuire and Tarashev (2008), deterioration in inter-bank liquidity adversely affects foreign banks' lending growth to the region. ${ }^{25}$ The coefficient estimates suggest that a 10-basis-point increase in the TED spread would lead, on average, to a roughly 0.2 percentage point reduction in the quarterly growth rate of total lending by global banks.

A weakening of parent banks' financial health has consistently led to slower growth in global banks' lending to LAC. A rise in one standard deviation (20 basis points) in banks ${ }^{6}$ EDF is associated with a 1.5 percentage point average decrease in the growth rate of foreign banks' lending in the subsequent quarter. This result is consistent with recent work by Čihák and Koeva Brooks (2009) that shows that bank loan supply in the Euro area moves in line with banks' financial soundness. ${ }^{26}$ Changes in banks ${ }^{6}$ lending standards in advanced economies also seem to have a statistically significant effect on the growth of foreign banks' ${ }^{6}$ credit to Latin America, once we control for other factors. ${ }^{27}$

Exchange rate depreciations are associated with a significant slowdown in the dollar value of foreign banks' lending during the same quarter. These estimates could be capturing mechanical valuation effects, as well as the impact of currency crises that occurred during

whereas in Europe and Central Asia more than 90 percent of foreign banks are headquartered in the European Union. Fixed effects also account for the special case of Panama, which is a regional banking center and is classified as an offshore center by BIS. It constitutes an outlier in the region, with foreign banks' claims accounting for 190 percent of GDP.

${ }^{25}$ As discussed by McGuire and von Peter (2009), such dollar shortages became particularly severe after the Lehman bankruptcy, which prompted the Federal Reserve to establish swap lines with other central banks, in particular in European countries.

${ }^{26}$ Our findings are also consistent with Haas and van Lelyveld (forthcoming), who analyze a large banklevel dataset of foreign banks' subsidiaries across the world to analyze what determines the credit growth of global banks' affiliates. Their results show that multinational bank subsidiaries with financially strong parent banks are able to expand their lending faster.

${ }^{27}$ In a recent paper, Herrmann and Mihaljek (2009) study the nature of spillover effects in cross-border bank lending flows from advanced to the emerging markets using confidential BIS bilateral data on locational banking statistics. They find that higher global risk aversion and higher expected market volatility seem to have been the most important channels through which spillover effects occurred during the crisis of 200708 . 
the sample period. ${ }^{28}$ The effect of other explanatory variables has the expected sign and is consistent with theory. Like Goldberg (2002) and Martinez-Peria, Powell and VladkovaHollar (2005), we find that home country conditions drive changes in foreign bank lending. Higher economic growth is associated with an increase in lending growth to the region during the same quarter, although its effect is imprecisely estimated ${ }^{29}$ Institutional improvements (as proxied by a more favorable economic and political risk rating) lead to stronger investor confidence and thus attract more foreign bank lending, a result also found by Papaioannou (2009).

Finally, we also estimate a different specification that allows shocks to global liquidity conditions, parent banks' financial health and lending standards in advanced economies to have differential effects across LAC countries, according to the share of foreign banks ${ }^{6}$ claims on that country that are denominated in local currency. For these purposes, we estimate the following specification:

$$
\begin{aligned}
F B L_{i j t}= & \beta_{0}+\beta_{1} \text { TED }_{t}+\beta_{2} \operatorname{EDF}_{t-1}+\beta_{3} \operatorname{LENDS}_{t-1}+\beta_{4} G \hat{D} P_{i t}+\beta_{5} \text { CRating }_{i t}+ \\
& \beta_{5} \operatorname{Deprec}_{i t}+\beta_{6} \operatorname{ShLC}_{i j t}+\beta_{7}\left(\operatorname{TED}_{t} x \operatorname{ShLC} C_{i j t}\right)+\beta_{8}\left(E D F_{t-1} x \operatorname{ShLC} C_{i j t}\right)+ \\
& \beta_{9}\left(\operatorname{LENDS}_{t-1} x \operatorname{ShLC} C_{i j t}\right)+\beta_{10}\left(\operatorname{Deprec}_{i t} x \operatorname{ShLC} C_{i j t}\right)+\lambda_{t}+\gamma_{i j}+\varepsilon_{i t}
\end{aligned}
$$

where $S h L C_{i j t}$ is the fraction of domestic-currency denominated claims of local affiliates in total claims of foreign banking system $j$ on country $i$ on quarter $t$. This ratio serves as a proxy for the share of foreign banks ' lending funded in domestic markets. ${ }^{30}$ We also included the interaction term $\left(\right.$ Deprec $\left._{i t} x S h L C_{i j t}\right)$, to control for the fact that exchange rate valuation effects from fluctuations in the dollar value of the domestic currency may be bigger in countries with a larger share of foreign banks' claims denominated in domestic currency.

The results, reported in the second column of Table 2, suggest that the transmission of global financial shocks through the foreign bank lending channel is significantly more muted in countries where foreign banks conduct a higher share of their lending in domestic currency. For example, a 1 percent increase in the TED spread is associated to a reduction in 4 percent in foreign banks ' lending in countries were all foreign banks ' credit is denominated in foreign currency. However, this effect is not significantly different from

\footnotetext{
${ }^{28}$ The literature suggests that borrowing conditions are likely to tighten for a country that experiences a currency collapse given the balance sheet effects due to currency mismatches.

${ }^{29}$ The positive effect of GDP growth is statistically significant only at the $12 \%$ confidence level.

${ }^{30}$ Claims booked outside the recipient economy (i.e., cross-border) are typically funded in international wholesale markets (in foreign currency). In most LAC countries, regulations require that domestic banks (including local affiliates of foreign banks) keep both sides of their balance sheets currency-matched. Thus, the domestic-currency share of total foreign banks' lending is a reliable indicator of the importance of local sources of funding (except in a few highly dollarized economies like Bolivia, Peru and Uruguay, were a substantial fraction of local deposits are denominated in foreign currency). See also footnote 32.
} 
zero in countries where more than 70 percent (approximately) of the lending is denominated in domestic currency. ${ }^{31}$ In other words, countries in which foreign banks' lending is largely extended through their local subsidiaries or branches (rather than crossborder operations) are less vulnerable to a "sudden stop" in foreign banks' financing.

Our results are consistent with results reported by Garcia-Herrero and Martinez Peria (2007), who show that countries in which a larger share of foreign bank lending is extended through local affiliates experience lower volatility in total foreign banks lending. ${ }^{32}$ Our findings are also in line with recent work by Raddatz (2009), who provides systematic evidence of the role of banks' reliance on wholesale funding in the international transmission of the liquidity crunch in September 2008. Using data on stock price returns of more than 600 individual banks across 44 countries, the author shows that banks that relied more heavily in non-deposit sources of funds experienced a significantly larger decline in market capitalization even after controlling for other determinants of stock prices. ${ }^{33}$

Overall, our results suggest that foreign banks` lending to Latin America does respond to funding constraints caused by liquidity conditions in the global inter-bank market and parent banks' own financial vulnerability. ${ }^{34}$ However, the size of the responses to the above shocks depends on the structure of lending to a given LAC country. The estimates suggest that the larger effects are to be observed on cross-border lending (which is largely denominated in foreign currency and funded in wholesale markets), while effects on lending from affiliates (especially in those countries with low dollarization of credit) are much smaller. ${ }^{35}$

\footnotetext{
${ }^{31}$ In this alternative specification, the positive effect of GDP growth on foreign banks' lending is economically and statistically significant at standard confidence levels.

${ }^{32}$ The share of foreign banks total lending denominated in local currency also serves as a proxy for the share of foreign banks' total claims on a country held by local affiliates, since cross-border lending is rarely extended in local currency, and lending by local affiliates is mostly denominated in local currency (except in a few dollarized countries like Peru, Bolivia and Uruguay). Data availability limitations preclude directly estimating separate models for cross-border lending and total lending through local affiliates. Such data breakdown is only available since 2005 , and only on an aggregate country-level basis.

33 Analyzing the post-crisis macroeconomic and financial sector performance for 58 advanced countries and emerging, Claessens, Dell'Ariccia, Igan and Laeven (2010) show that banks' dependence on wholesale funding help to account for the amplification and global spread of the financial crisis.

${ }^{34}$ Using data through 2000, Goldberg (2001) shows that movements in U.S. bank lending to Latin American countries are closely tied to economic conditions in the parent country.

${ }^{35}$ It should be noted the model was estimated over a period that was mostly tranquil (except for the last quarter of 2008), but it is being used to inform future lending growth in the wake of a shock of unprecedented magnitude. That said the model performed very well in predicting the sudden turning point and drop of foreign bank lending to LAC in 2008Q4. With data up to 2008Q4, the model predicted a yearon-year growth in total foreign banks' lending to LAC for the first quarter of 2009 of 7.5 percent- very close to 5.5 percent actually observed (see IMF, 2009a).
} 


\section{Was There a Retrenchment Post-Lehman? Latest Cross-Regional EVIDENCE}

BIS banking data up to the second quarter of 2009 were available at the time of writing, allowing us to examine how international banks responded in the three quarters following the Lehman Brothers event of September 2008. Because this period of financial turmoil was characterized by unusually large fluctuations of several emerging market currencies, the discussion below focuses on movements in lending by foreign banks that exclude currency valuation effects. ${ }^{36}$

For most regions around the world, total lending by global banks (both cross-border and through local subsidiaries) had begun to slow down or even contract by late 2007, and this trend continued through the latest data available for the second quarter of 2009 (Figure 9).$^{37}$ Yet in the case of Latin America - where previous growth rates of total lending had not been as rapid as elsewhere- foreign banks' lending only began to be strongly affected in the final quarter of 2008, when total lending of foreign banks to the region as a whole contracted by about 5 percent within the quarter. ${ }^{38}$ By end- June 2009, and consistent with the sources of resilience identified in previous sections, total outstanding foreign banks ${ }^{6}$ claims in Latin America had increased slightly when compared with end-September 2008 (when measured in constant exchange rates). This is in marked contrast with the behavior in emerging Europe, emerging Asia and Africa and Middle East, which actually saw a contraction in the total foreign banks' claims by up to 7 percent over the same period (see Figure 10).

In addition, and in line with the empirical results reported in the previous section, the behavior of local affiliates and their parent banks diverged dramatically since the last quarter of 2008. The stock of cross-border claims on LAC, which had been growing at annual rates of almost 40 percent in previous quarters, abruptly contracted within the fourth quarter of 2008 (by almost 20 percent) and then continued a steep decelerationtaking year-on-year growth by end-June 2009 to almost -10 percent (see Figure 11). ${ }^{39}$ On

\footnotetext{
${ }^{36}$ Adjusting for exchange rate valuation effects can be important not only in light of the sharp depreciations in the last semester of 2008 (especially in Brazil and Mexico, which together account for about two-thirds of foreign bank claims on the LAC region), but also because these depreciations were preceded by sustained periods of domestic currency appreciation in many emerging markets.

${ }^{37}$ Cross-border lending by foreign banks' headquarters, in particular, retrenched significantly in 2008 , contracting in the final quarter of 2008 at the fastest rate since records began 30 years ago.

${ }^{38}$ Contractions varied in size, but did occur in most countries of the region (see Table 1). Those countries more dependent on cross-border lending - the component of foreign banks lending that is more sensitive to global funding conditions - were the most affected.

${ }^{39}$ In addition to the factors discussed earlier, it is possible that recent bank support or rescue programs in advanced economies may be accelerating the curtailment of cross-border bank flows. In particular, banks receiving public support may feel pressure to expand domestic lending at the expense of their foreign operations.
} 
the other hand, total lending by local affiliates of foreign banks gradually decelerated, but managed to grow at a healthy pace in the post-Lehman period.

Across foreign banks of different nationality, Spanish banks showed the most resiliency in their lending behavior. Cross-border lending by Spanish banks has decelerated somewhat, but has held up much more than the rest of the foreign banks (in particular those from the US), which display the "deleveraging" features (Figure 12). ${ }^{40}$ For local currency lending, the data suggests that Spanish banks have been increasing its market share in the region, as the aggregate of the rest of the banks retreat. ${ }^{41}$ Two factors can explain the more robust behavior of Spanish banks. First, 60 percent of Spanish banks' claims in emerging markets are long-term, while that of U.S. banks is close to 20 percent (McGuire and Tarashev, 2008). ${ }^{42}$ This suggests that U.S. banks can in principle adjust large portions of their exposures more easily than Spanish banks can. More importantly, overseas affiliates of Spanish banks are required to have financial autonomy in terms of liquidity from their parent banks, funding their operations in each country with retail deposits - thus operating very much like their domestic counterparts (but with foreign capital). This made Spanish banks' locally established offices more resilient and better prepared to withstand the global financial shock.

\section{INTERPRETING THE EVIDENCE}

The evidence presented suggests that four key features of global banks' lending to LAC region muted the transmission and amplification of global financial shocks to the region. First, Latin America's lower reliance on foreign banks' cross-border credit made it less exposed to the risk of a homeward flow of foreign banks' assets. Because cross-border lending is typically funded in international markets, it tends to be highly sensitive to movements in global inter-bank market conditions. On the other hand, and as discussed in Garcia-Herrero and Martinez-Peria (2007), given that local lending activities require paying higher fixed and irreversible costs (such as local networks and real assets), these flows tend to be more stable and less responsive to negative shocks than cross-border lending. Furthermore, local affiliates could have a better understanding of the domestic conditions and projects that make them less susceptible to engage in the type of generalized withdrawal that characterize herding behavior when conditions deteriorate.

\footnotetext{
${ }^{40}$ Using bank-level data for 17 LAC countries between 1996 and 2007, Galindo, Izquierdo and RojasSuarez (2010) find that Spanish banks tend to react less than other foreign banks to changes in risk conditions in international capital markets.

${ }^{41}$ The jump observed in the figure in 2008.3 for Spanish banks ' lending in local currency corresponds to the purchase by Santander of ABN-AMRO's affiliates in Brazil and Uruguay.

${ }^{42}$ Information about residual maturity is available only for cross-border and local affiliates ${ }^{6}$ lending denominated in foreign currency. For the LAC region as a whole, the share of total foreign banks' claims with short maturity dropped from 54 percent in 1997 to 42 percent in 2008 . Thus, the maturity composition of lending to the LAC region has shifted toward the long term, and refinancing risk remains low compared with developing countries as a whole.
} 
Second, foreign-owned affiliates ' high reliance on stable domestic deposits has limited the potential destabilizing effects coming from solvency problems or tight liquidity conditions faced by banks in the major industrialized economies. Third, the share of foreign bank lending denominated in foreign currency is relatively low, reducing the likelihood of financial stress and credit contraction during crisis periods. Lending denominated in foreign currency brings additional risks stemming from swings in exchanges rates. For example, domestic currency depreciation could push up the cost of borrowing or increase expected defaults when borrowers have currency mismatches, leading to a stronger retrenchment in credit. ${ }^{43}$

Fourth, the large global bank players that are the most involved in emerging Europe are not among those with the most significant presence in Latin America. During the recent crisis, this limited the cross-regional contagion effects that can occur through a -ommon bank lender effect," in which losses in a country would cause a global bank to liquidate its assets or cut credit lines to its subsidiaries in order to restore its capital adequacy ratios. ${ }^{44}$ In the most recent period, bank lending ties have been a major channel of transmission among some countries, especially in emerging Europe where cross-border lending has supported more heavily the banking sector (see Canales-Kriljenko et al., 2010 and Arvai et al., 2010).

Arguably, the bigger contraction in foreign banks ' lending to other regions of the world, especially emerging Europe, could be also reflecting bigger demand-side shocks, caused by severe recessions and a contraction in credit demand from households and firms. ${ }^{45}$ Thus, more research is needed to disentangle the importance of credit developments in the pre-crisis period, business-cycle conditions during the crisis and global banks' expansion strategies and business models in explaining the cross-regional variation in foreign banks ${ }^{\text {‘ }}$ lending. ${ }^{46}$

\footnotetext{
${ }^{43}$ In the case of emerging Europe, foreign-owned banks played a key role in fueling a credit boom during the pre-crisis period. As noted by Porzecanski (2009), foreign-owned affiliates were largely vehicles through which parent banks' resources were loaned out domestically. Thus, rapid credit growth, large capital transfers to subsidiaries and foreign currency lending were all the result of the expansion strategy of Western Banks.

${ }^{44}$ See Calvo and Reinhart (1996) and Van Rijckeghem and Weder (2000).

${ }^{45}$ As discussed in Zettelmeyer at al. (2010), by the time the global financial crisis erupted, emerging Europe was experiencing greater financial vulnerabilities than Latin America. As a result, economic activity in European emerging markets was hit harder than in any other emerging market region.

${ }^{46}$ In a recent paper, Cetorelli and Goldberg (2010) examine the behavior of foreign banks ‘ lending to countries in Europe, Asia, and Latin America, isolating lending supply shocks to banks in advanced economies from lending demand shocks in recipient countries. Their results suggest that the strongest contraction in foreign banks' lending on emerging European countries was likely due to effective creditsupply changes by global banks.
} 


\section{CONCLUSION}

The turmoil in international credit markets that began in mid-2008 raised questions about the level and stability of foreign banks' financing to emerging market countries. In the case of LAC, growth in foreign banks' lending did slow rapidly after the collapse of Lehman in the third quarter of 2008 - but the retrenchment of foreign banks ${ }^{6}$ credit to Latin America and the Caribbean was significantly less severe compared to other emerging markets.

Our empirical results suggest that the negative impact of the financial crisis on foreign banks' lending to Latin America and the Caribbean has been cushioned by the specific nature of foreign banks' operations in the region. The expansion of their activities in Latin America and the Caribbean in the last five years has largely taken the form of increased domestic currency lending by their local affiliates, rather than direct cross-border lending in foreign currencies from headquarters. Moreover, local affiliates ' funding mostly came from an expanding domestic deposit base, rather than from parent banks or offshore wholesale markets, providing a stable source of funding during the crisis. These characteristics muted the transmission of global financial shocks to the Latin American economies through the foreign bank lending channel.

The recent experience of foreign bank lending to Latin America and the Caribbean suggest a few lessons for assessing and mitigating the volatility of foreign bank lending, and are relevant to policy discussions regarding the costs and benefits of opening the domestic banking sector to foreign competition. Our results indicate that foreign bank lending that is extended in domestic currency - which is typically funded with local deposits by local affiliates - tends to be more resilient to external financial shocks. In many LAC countries, these characteristics of foreign bank financing acted as a firewall against the transmission of global financial shocks, and could plausibly explain why LAC as a whole has not been struck as hard as other emerging markets by the global deleveraging and pullback of foreign bank credit. Policies to foster foreign bank lending in domestic currency and funded by local deposits can allow emerging market economies to obtain the benefits of global bank lending, while creating more resilient mechanisms of financial integration. 


\section{APPENDIX}

\section{Data Used in Empirical Analysis}

\section{Dependent Variable}

Total Foreign Banks' Claims: Source BIS, Table 9A: Consolidated foreign claims of reporting banks in immediate borrower basis. BIS variable code:

Q:M:F:B:S:[lender]:[borrower]

BIS data does not discriminate between cross-border claims (i.e., claims booked outside the host country) and local claims by foreign-owned banks on a bilateral basis. BIS statistics on local claims only capture those denominated in local currency. Foreign currency-denominated local claims are combined with cross-border claims (in all currencies) and reported under what the BIS calls international claims"،

\section{$\underline{\text { Explanatory Variables }}$}

$T E D \_$spread $=\left(L I B O R \_3 m-U S T B i l l \_3 m\right) * 100$. Averaged over monthly frequency to obtain quarterly data.

LIBOR_3m: 3-Month London Interbank Offer Rate: Based on US\$ (in \%). Haver code: FLOD3@USECON.

US TBill_3m: 3-Month Treasury Bill Market Bid Yield at Constant Maturity ( in\%). Haver code: FCM3M@USECON.

OIS_Spread $=($ LIBOR_3m-Overnight Index Swap_3m $) * 100$. Averaged over monthly frequency to obtain quarterly data.

Overnight Index Swap_3m: 3-Month overnight index swap. Haver Code: 111fiois_3m.

Lending Standards: Net percentage of banks reporting tightening standards for loans. Source: Bank of Japan; European Central Bank; Federal Reserve; and IMF staff estimates.

Exchange Rate: End of period exchange rate for the borrowing country, in domestic currency per dollar. Source IFS, IFS code [IFS countrycode]..AE.ZF...

Composite Risk Rating: From International Country Risk Guide (ICRG). Averaged over monthly frequency to obtain quarterly data.

Expected Default Frequency: Forward-looking, one-year default probabilities calculated by Moody's KMV for each publicly listed bank based on a contingent claims approach that uses equity market information combined with balance sheet data. For our analysis, we first average daily EDF data to obtain a quarterly series for each bank in each of the 14 
BIS-reporting countries. Within each country, we take the median over those banks that are internationally active to generate time-varying financial soundness measures for each banking system.

\section{Further Details on the Construction of Charts}

\section{Use of Consolidated and Locational BIS Baking Statistics}

All Tables and Figures (except Figure 5) rely on Consolidated Baking Statistics. Figure 5 is the only one where we use Locational Baking Statistics. It shows data on the amount outstanding of external claims of BIS-reporting banks in advanced economies vis-a-vis the banking sector in each individual country (were the banking sector includes both local affiliates and unrelated parties). Note that in this case, creditor data is reported on a residence basis (i.e. host country) rather than on a nationality basis (i.e. home country).

\section{Adjustment for Exchange Rate Valuation Effects}

BIS data on total foreign banks' claims correspond to end-period values, expressed in U.S. dollars. Thus, changes in the stock of foreign banks" outstanding claims incorporate mechanical exchange rate valuation effects, and so may differ from net lending flows. Currency valuation effects can at times be significant, especially in countries where local currency-denominated lending represents a significant portion of the total.

To express changes in total foreign claims in exchange rate-adjusted terms, we adjust the local currency-denominated portion of foreign banks' claims using a nominal exchange rate index for each country with base year 2005Q4. This adjustment is used in Table 1 and Figures 9, 10, 11, 12 and 17. To obtain the amount outstanding of foreign banks' claims that is in domestic currency we used local claims by local affiliates (-Fable 9AL: Local Currency Claims on Local Residents - on immediate borrower basis"). This assumes that all cross-border lending is denominated in foreign currencies, which is a reasonable assumption for the case of Latin America. Finally, we did not perform any valuation adjustment on the stock of international claims, as BIS does not provide information on the breakdown by individual foreign currencies. 
Table 1. Foreign Banks' Lending to LAC: Developments as of end-June 2009 (Percent change in U.S. dollar values)

\begin{tabular}{|c|c|c|c|c|}
\hline \multirow[b]{2}{*}{ Region/Country } & \multicolumn{2}{|c|}{ Quarterly Change } & \multicolumn{2}{|c|}{ Annual Change } \\
\hline & Actual & $\begin{array}{l}\text { Valuation } \\
\text { Adjusted 2/ }\end{array}$ & Actual & $\begin{array}{l}\text { Valuation } \\
\text { Adjusted 2/ }\end{array}$ \\
\hline $\begin{array}{l}\text { Latin America and } \\
\text { the Caribbean }\end{array}$ & 7.3 & 0.9 & -8.8 & 1.7 \\
\hline $\begin{array}{l}\text { Brazil } \\
\text { Mexico }\end{array}$ & $\begin{array}{c}16.9 \\
4.5\end{array}$ & $\begin{array}{r}5.4 \\
-1.5\end{array}$ & $\begin{array}{l}-12.3 \\
-13.0\end{array}$ & $\begin{array}{c}-1.3 \\
4.5\end{array}$ \\
\hline Other South America & 2.9 & -0.4 & -2.3 & 1.0 \\
\hline $\begin{array}{ll}\text { o/w } & \text { Argentina } \\
& \text { Chile } \\
& \text { Colombia } \\
& \text { Peru }\end{array}$ & $\begin{array}{c}0.2 \\
4.1 \\
11.4 \\
-5.3\end{array}$ & $\begin{array}{r}0.6 \\
-1.4 \\
1.8 \\
-6.6\end{array}$ & $\begin{array}{l}-14.2 \\
0.8 \\
-4.3 \\
-2.7\end{array}$ & $\begin{array}{c}-4.6 \\
1.8 \\
4.5 \\
-2.8\end{array}$ \\
\hline $\begin{array}{l}\text { Central America } \\
\text { o/w Costa Rica } \\
\text { Guatemala }\end{array}$ & $\begin{array}{l}1.5 \\
-4.2 \\
-6.1\end{array}$ & $\begin{array}{r}1.6 \\
-3.6 \\
-6.0\end{array}$ & $\begin{array}{l}1.9 \\
-7.4 \\
-8.5\end{array}$ & $\begin{array}{l}2.2 \\
-5.4 \\
-6.9\end{array}$ \\
\hline $\begin{array}{l}\text { Caribbean } \\
\text { o/w Dominican Republic } \\
\text { Grenada }\end{array}$ & $\begin{array}{l}-2.1 \\
-0.7 \\
6.2\end{array}$ & $\begin{array}{l}-2.0 \\
-0.7 \\
6.2\end{array}$ & $\begin{array}{c}1.4 \\
-41.3 \\
5.5\end{array}$ & $\begin{array}{l}3.6 \\
-40.9 \\
5.5\end{array}$ \\
\hline $\begin{array}{l}\text { Memo item } \\
\text { Emerging Europe }\end{array}$ & 6.4 & 2.5 & -14.5 & -5.9 \\
\hline Emerging Asia & 3.8 & 1.6 & -14.2 & -10.8 \\
\hline Africa \& Middle East & 2.7 & -1.7 & -4.0 & -3.1 \\
\hline
\end{tabular}

Sources: Bank for International Settlements; and IMF, International

Financial Statistics.

1 / Includes cross-border lending and lending by foreign-owned local affiliates in each country.

2/ Adjusts for exchange rate effects on foreign bank lending denominated in domestic currency. 


\section{Table 2. Determinants of Foreign Banks' Lending to Latin America 1999Q4-2008Q4; Panel OLS with Fixed Effects}

Dependent Variable: Quarterly Percent Change in Total Foreign Banks' Lending

\begin{tabular}{|c|c|c|}
\hline & \multirow{2}{*}{$\frac{\text { Average effects }}{(1)}$} & \multirow{2}{*}{$\begin{array}{c}\text { Differential effects } \\
(2)\end{array}$} \\
\hline & & \\
\hline TED spread & $\begin{array}{l}-0.02 * * \\
(0.01)\end{array}$ & $\begin{array}{l}-0.04 * * * \\
(0.01)\end{array}$ \\
\hline TED spread $x$ Share of LCL & & $\begin{array}{l}0.06^{* * *} \\
(0.02)\end{array}$ \\
\hline Parent Bank's Financial Stress & $\begin{array}{l}-7.72 * * * \\
(1.69)\end{array}$ & $\begin{array}{l}-11.64 * * * \\
(2.84)\end{array}$ \\
\hline Parent Bank's Financial Stress $x$ Share of LCL & & $\begin{array}{l}13.22 * \\
(6.97)\end{array}$ \\
\hline Tighter lending standards & $\begin{array}{l}-0.09 * * * \\
(0.01)\end{array}$ & $\begin{array}{l}-0.11 * * * \\
(0.02)\end{array}$ \\
\hline Tighter Lending Standards $\times$ Share of LCL & & $\begin{array}{c}0.12 * \\
(0.07)\end{array}$ \\
\hline GDP growth of borrower & $\begin{array}{r}0.17 \\
(0.10)\end{array}$ & $\begin{array}{l}0.22 * \\
(0.11)\end{array}$ \\
\hline Composite indicator of credit rating & $\begin{array}{l}0.47^{* *} \\
(0.19)\end{array}$ & $\begin{array}{l}0.47^{* *} \\
(0.19)\end{array}$ \\
\hline Share of LCL & & $\begin{array}{l}16.56 \\
(3.28)\end{array}$ \\
\hline Depreciation & $\begin{array}{l}-0.11 * * * \\
(0.02)\end{array}$ & $\begin{array}{r}0.01 \\
(0.03)\end{array}$ \\
\hline Depreciation x Share of LCL & & $\begin{array}{l}-0.60 * * * \\
(0.15)\end{array}$ \\
\hline Time (quarter) dummies & Yes & Yes \\
\hline Borrower/lender fixed effects & Yes & Yes \\
\hline & nostics & \\
\hline Number of observations & 5,276 & 4,766 \\
\hline$R^{2}$ & 0.03 & 0.03 \\
\hline
\end{tabular}

Source: Authors' calculations.

1/ This table reports the panel fixed effect regression described in equation (1) the text. The variables Expected Default Probability and Lending Standards are entered with one lag. The sample used excludes extreme observations, defined to be those below the25th, and above the 98th, percentile of the distribution of percent changes in foreign banks' for the whole sample. Robust standard errors are clustered at the borrower country level. Asterisks denote significance of coefficients, with ${ }^{* * *},{ }^{* *}$, and * indicating significance at the $1 \%, 5 \%$ and $10 \%$ level, respectively. 
Figure 1. Share of Banking Assets Held in Subsidiaries or Branches of Global Foreign Banks 1/

(Percent of total banking system assets, end-2008)

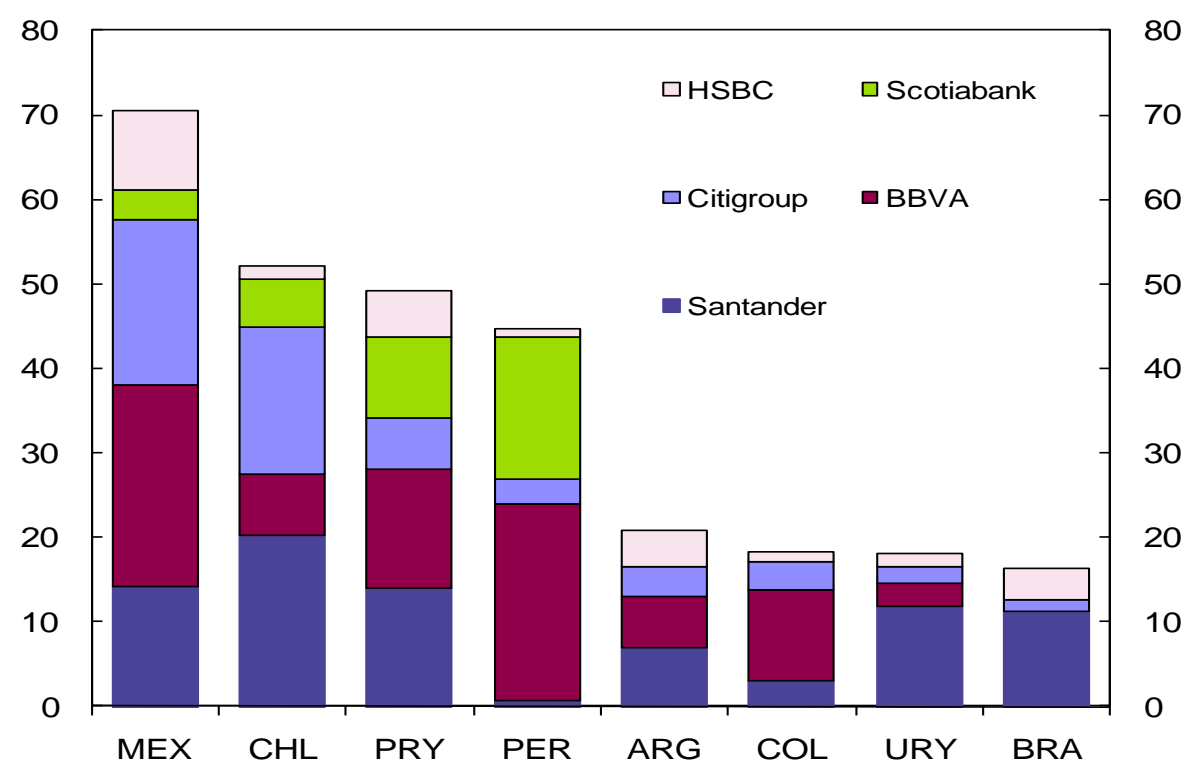

Sources: National authorities; Bankscope; and authors' calculations. $1 /$ Included in the calculations are the five main foreign banks with global presence. In some countries, the actual share of foreign bank ownership of assets could be higher due to the presence of other international or regional banks.

Figure 2. Foreign Banks' Lending as a Share of GDP, $20081 /$ (In percent)

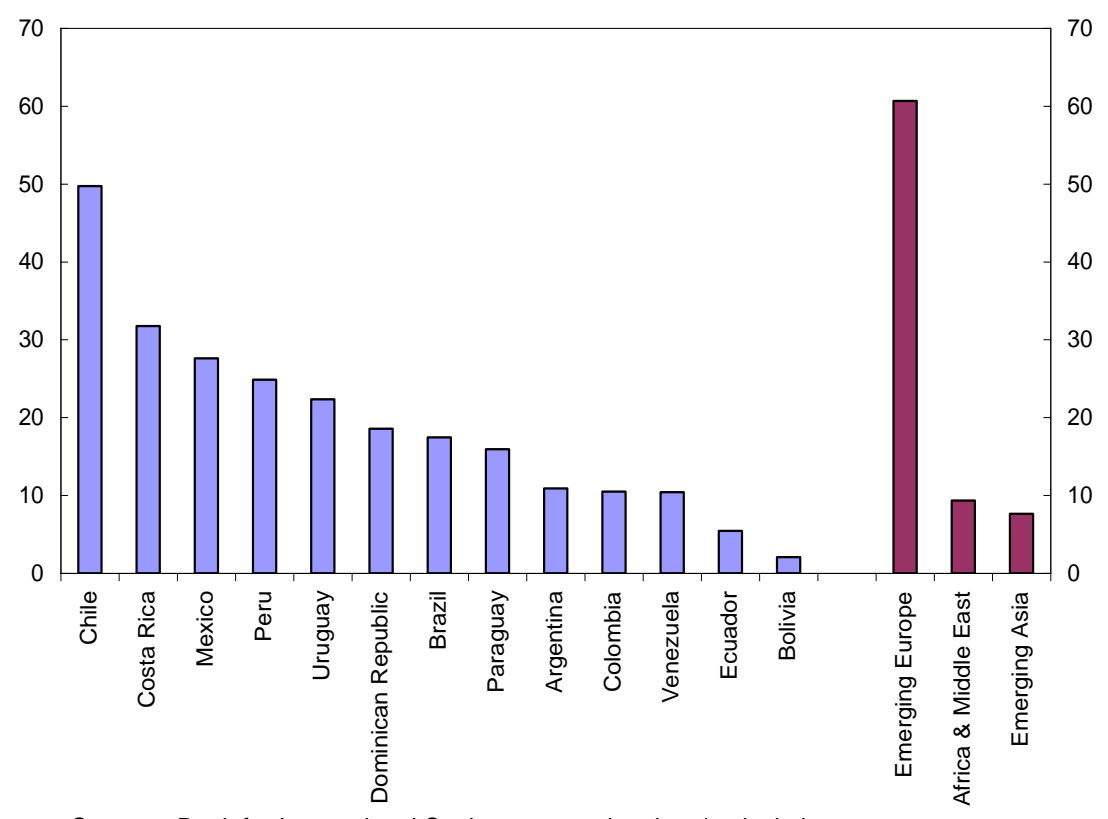

Sources: Bank for International Settlements; and authors' calculations.

$1 /$ Includes cross-border lending and lending by foreign-owned local affiliates in each country. Note: Regional data correspond to the median across countries. 
Figure 3. Share of Foreign Banks' Lending Extended Through Their Local Affiliates, 2008

(In percent of total)

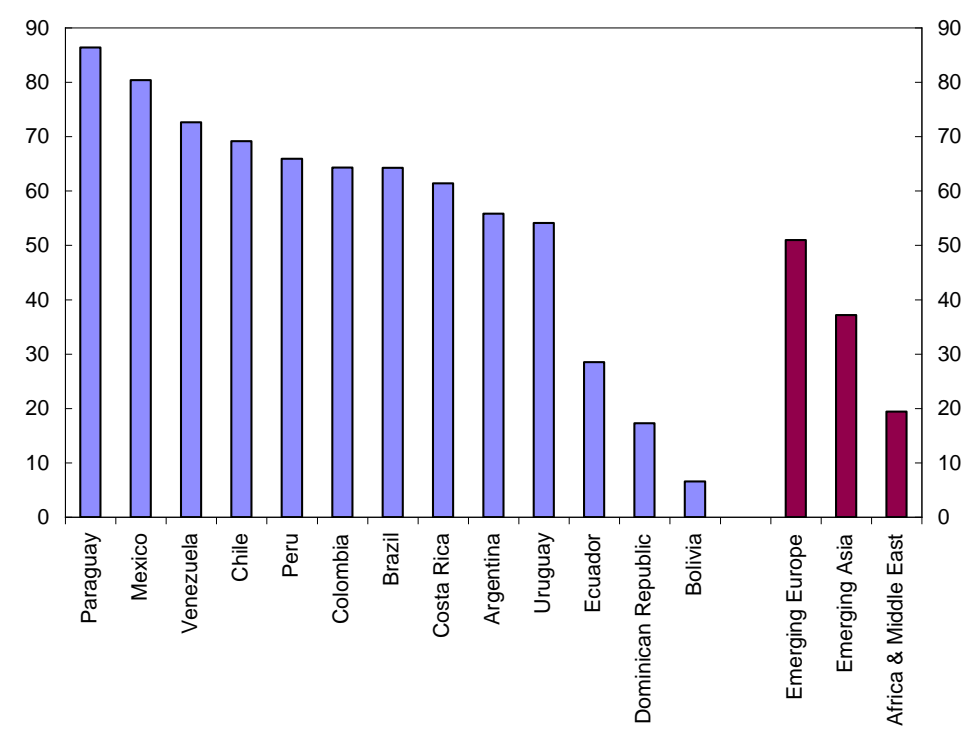

Sources: Bank for International Settlements; and authors' calculations. Note: Regional data correspond to the median across countries.

Figure 4. Deposit-to-Loan Ratios in Foreign-Owned Local Affiliates, 2007 1/ (In percent)

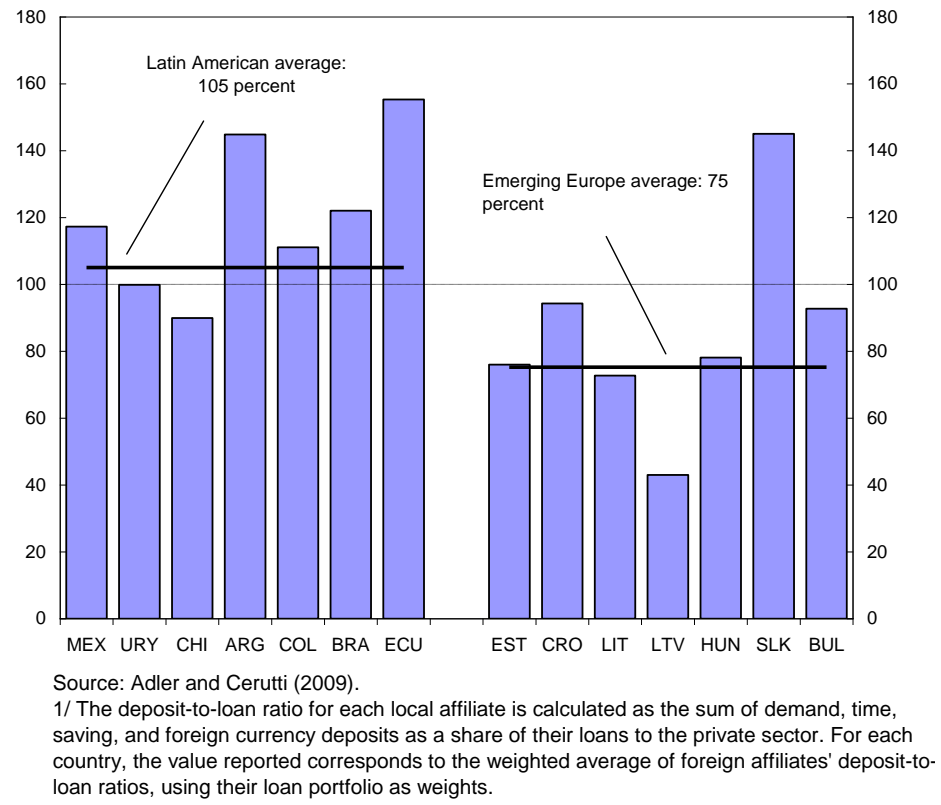


Figure 5. Foreign Banks' Cross-Border Lending to Banking Sector in Emerging Markets, 20081 I

(In percent of GDP)

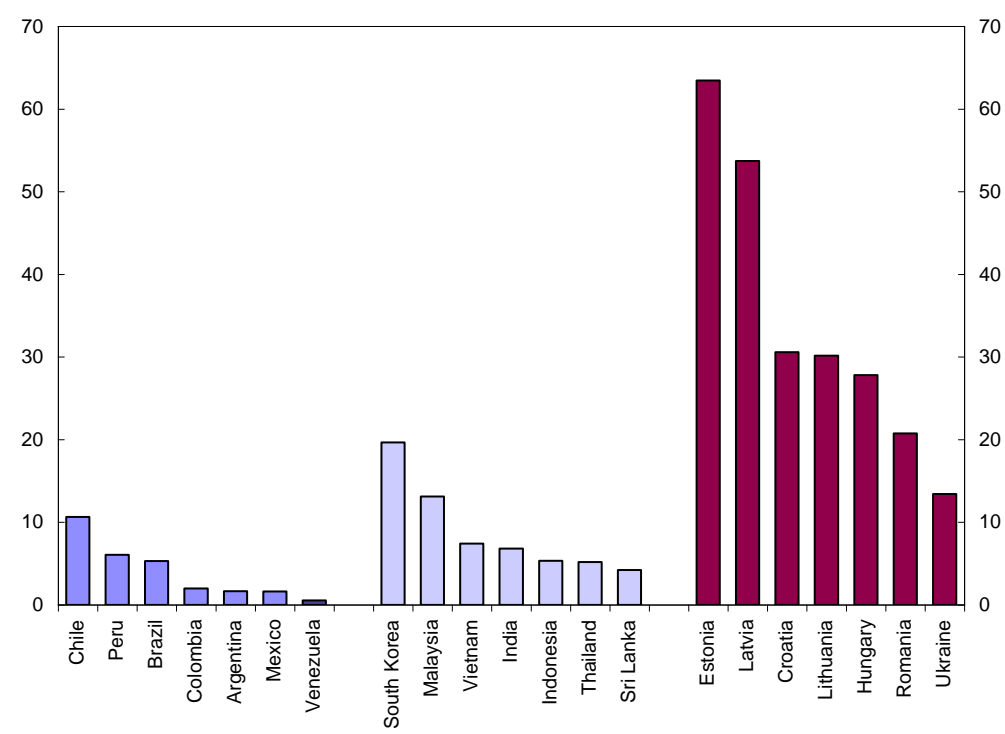

Source: Authors' calculations.

1/ Foreign banks' overseas lending to domestic-owned banks and foreign-owned local affiliates in each country.

Figure 6. Share of Foreign Banks' Lending Denominated in Local Currency, 2008 (In percent of total)

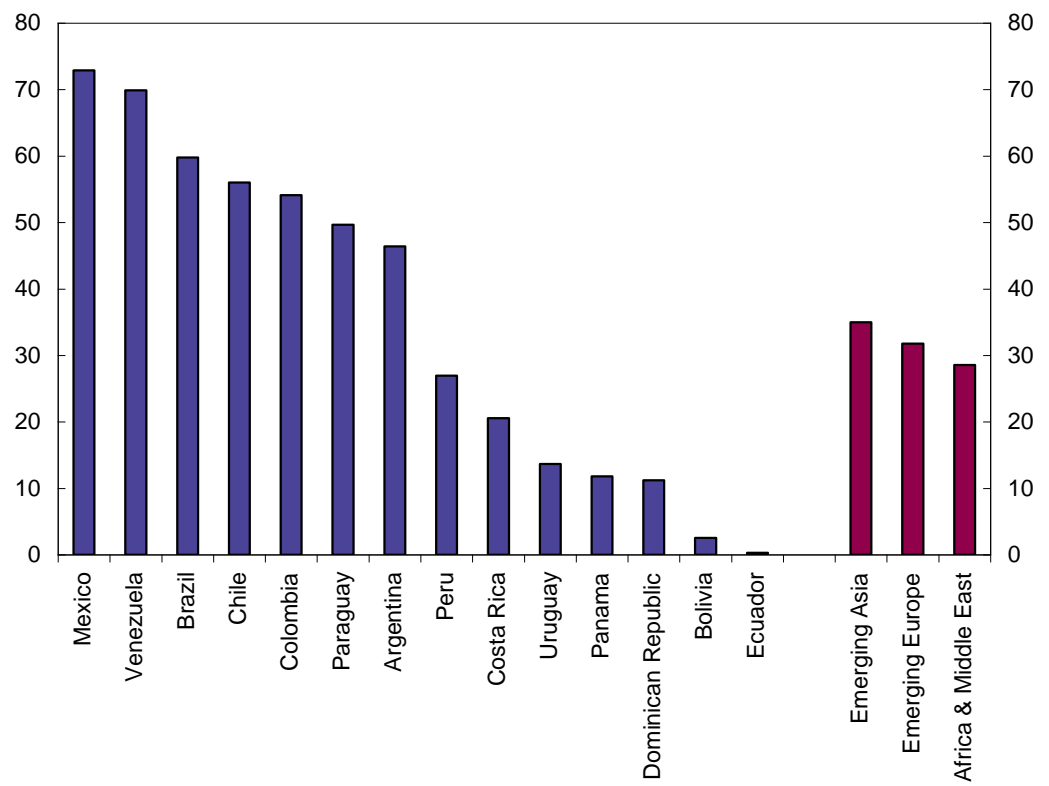

Sources: Bank for International Settlements; and authors' calculations. Note: Regional data correspond to the median across countries. 
Figure 7. Total Foreign Banks' Lending in Foreign Currency in Emerging Markets

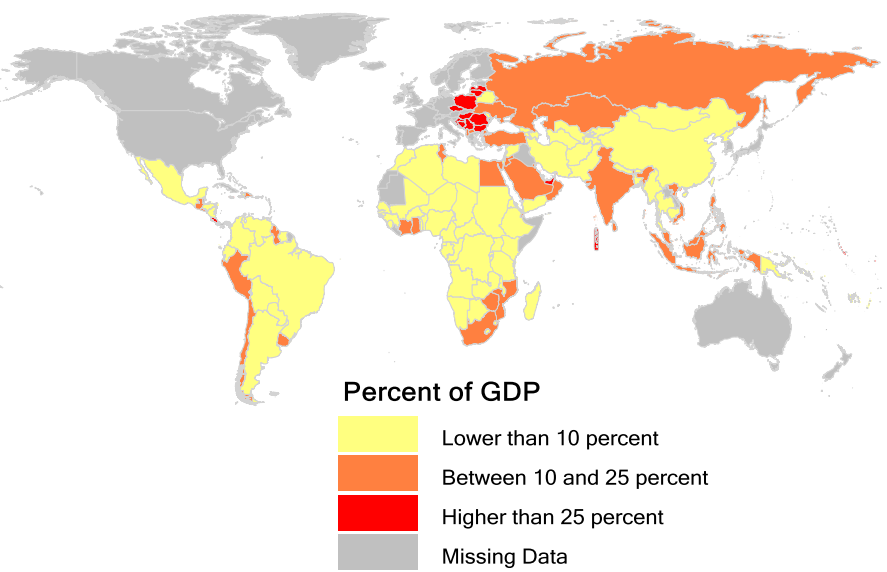

Figure 8. Foreign Lending by Bank Nationality (In percent, end 2008)

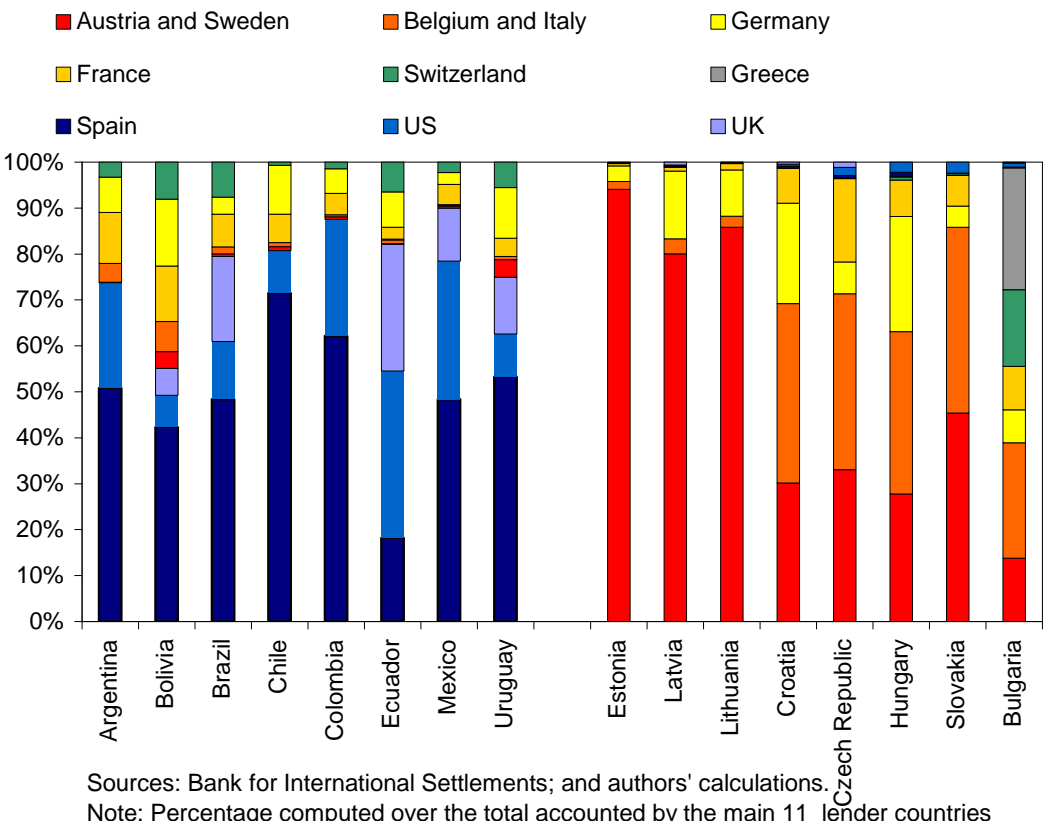


Figure 9. Growth in Foreign Banks' Lending, by Region 1/ (Annual percent change, exchange rate-adjusted)

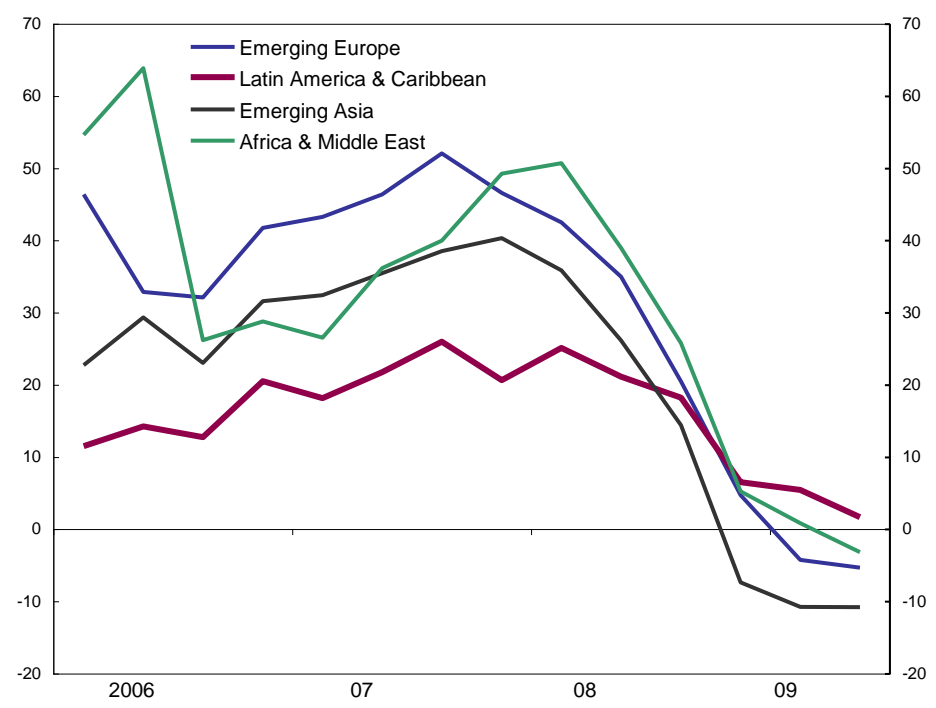

Sources: Bank for International Settlements; IMF, International Financial Statistics; and authors' calculations.

1 / Includes cross-border lending and lending by foreign-owned local affiliates in each country.

Figure 10. Change in Foreign Banks' Total Outstanding Claims since Lehmann Demise, by Region 1/

(Percent change, exchange rate-adjusted)

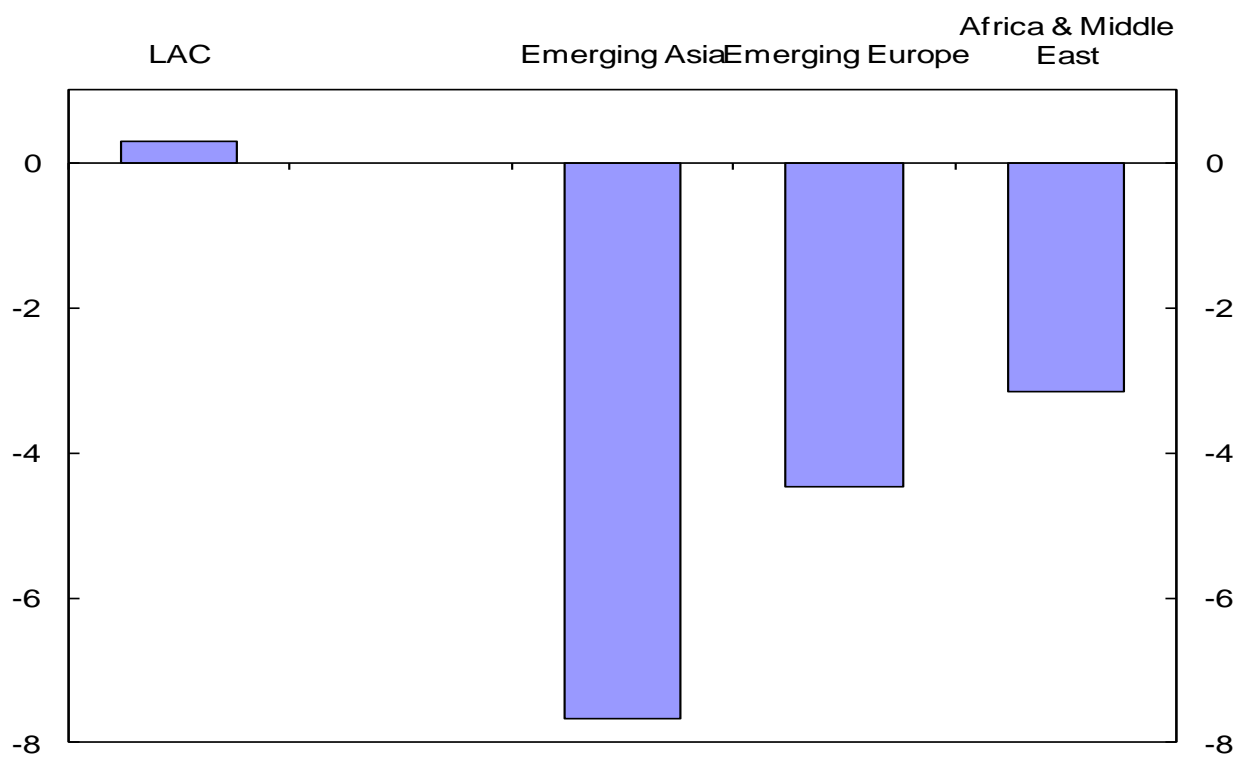

Sources: Bank for International Settlements; and authors' calculations. 1/Percentage change between end-September 2008 and end-June 2009 in gross outstanding claims (both cross-border and by foreign-owned local affiliates) measured in exchange-rate adjusted terms. 
Figure 11. Channels of Foreign Banks' Lending to LAC: Differences in their Behavior (Annual percent change in U.S. dollar value)

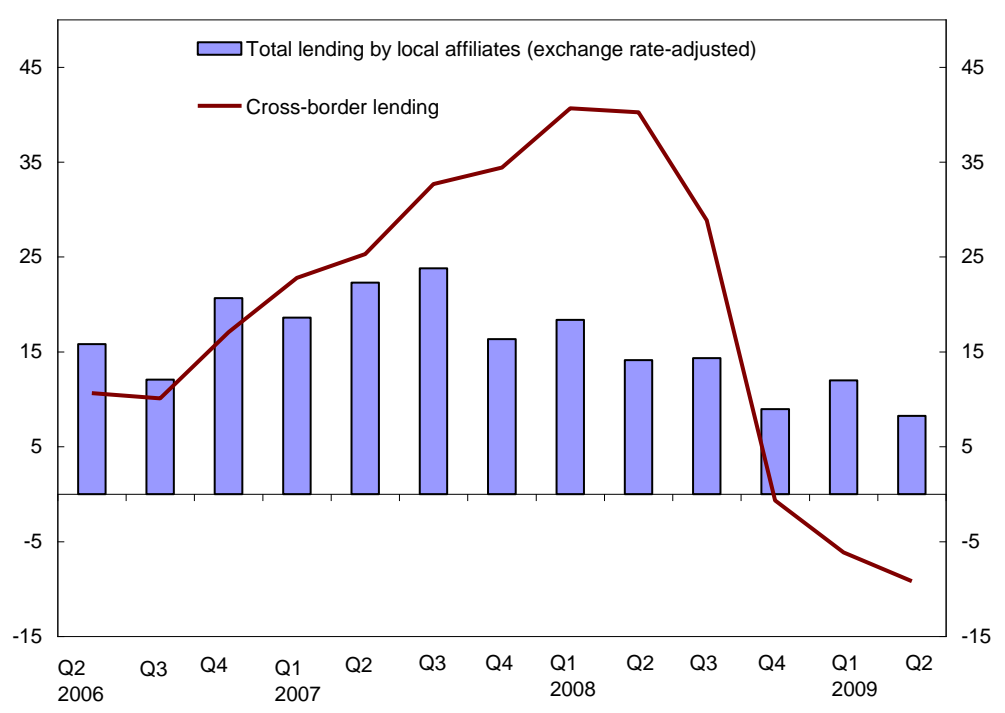

Sources: Bank for International Settlements; and authors' calculations.

Figure 12. Spanish Banks Compared to U.S. Banks in Terms of Lending to LAC (Annual percent of change; exchange rate adjusted)

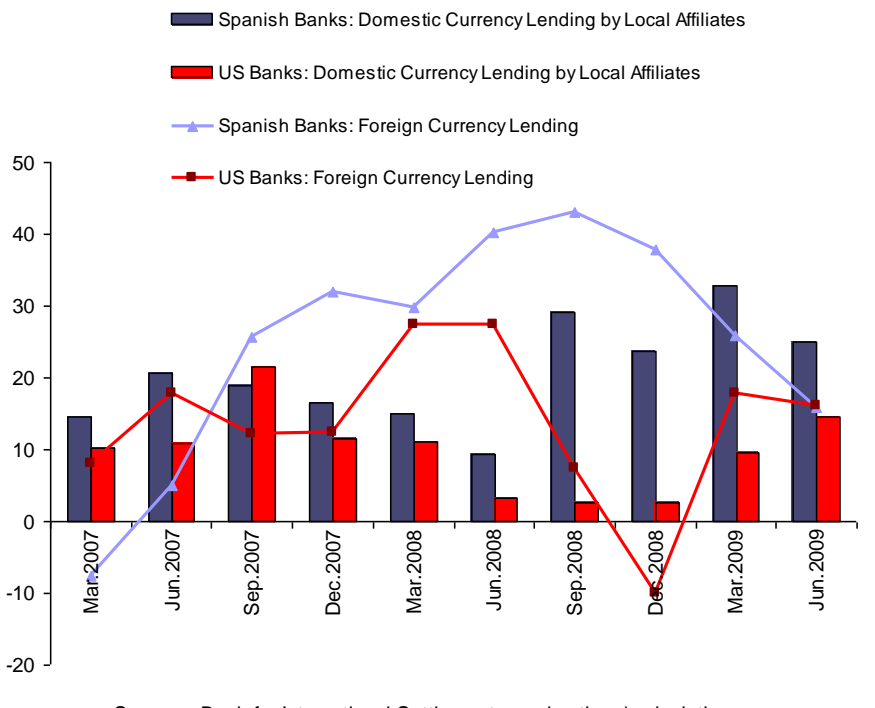

Sources: Bank for International Settlements; and authors' calculations. 
Figure 13. Total Foreign Banks' Lending to LAC Region 1/

Figure 13. Total Foreign Bank Lending (Cross-Border and by Local Affiliates) to LAC Region

Total foreign banks' lending (in billions of nominal US\$,

Growth in foreign banks' lending (quarterly percent change, right left scale) scale)
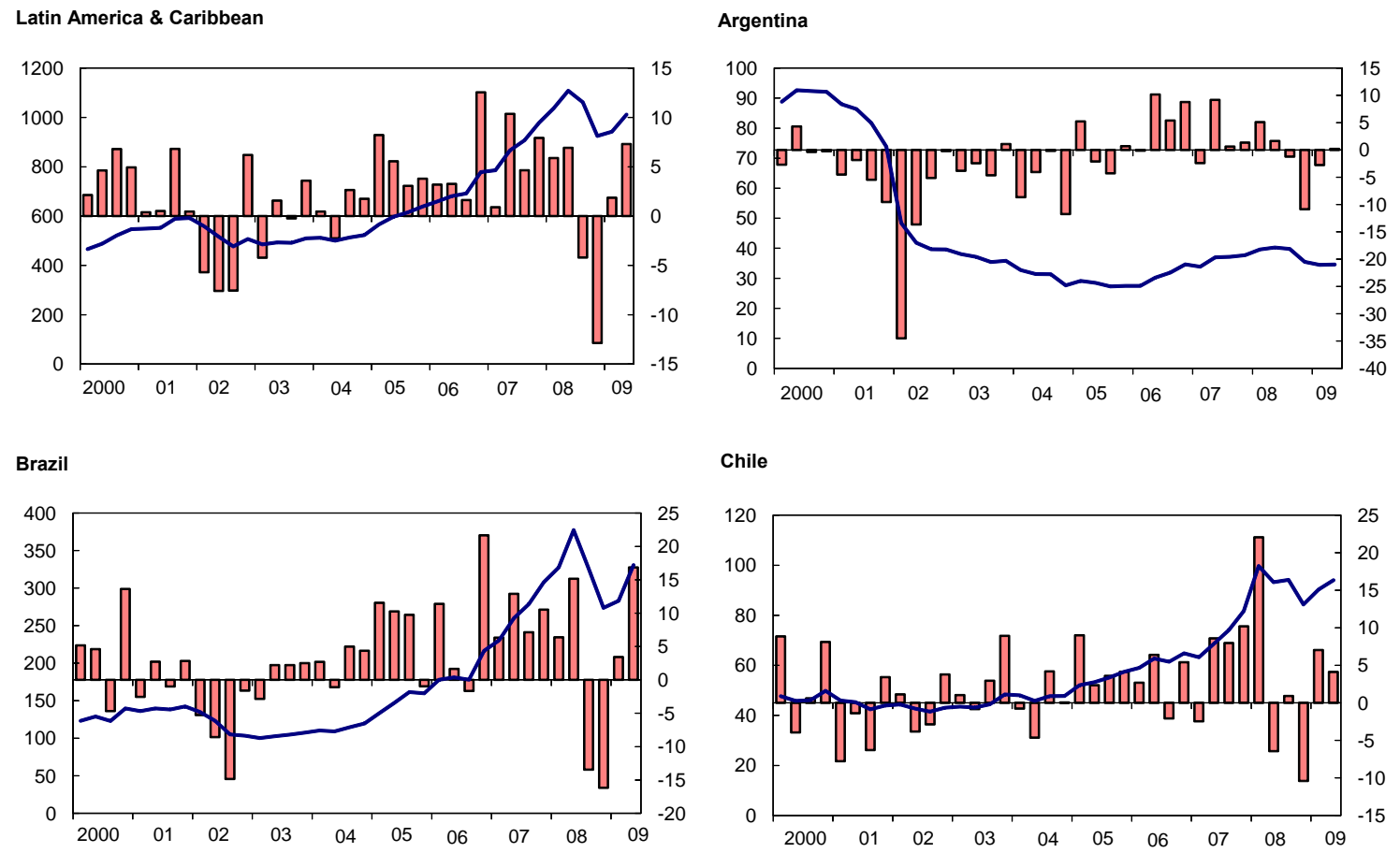

Colombia

Mexico
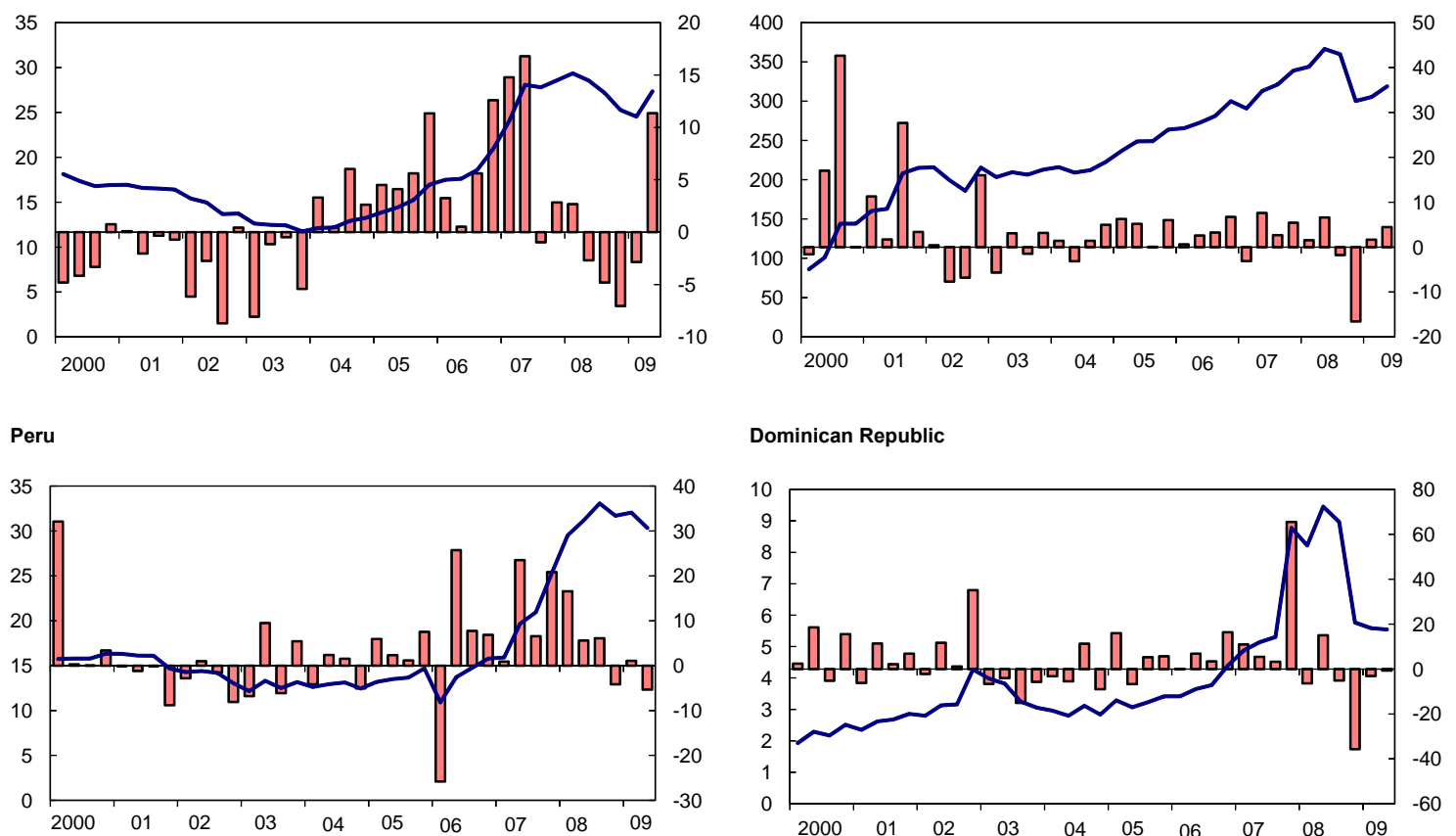

Dominican Republic

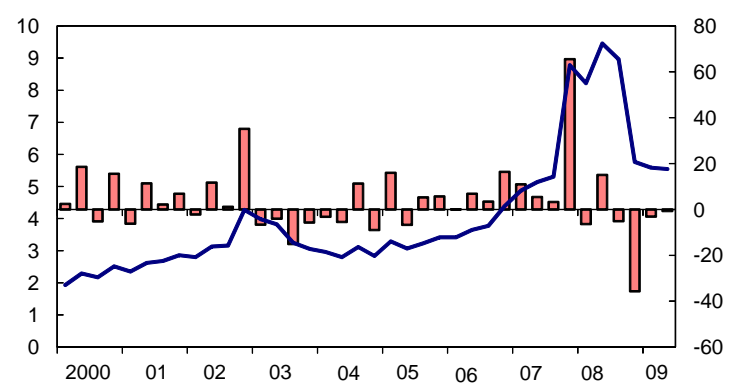

Sources: Bank for International Settlements and IMF staff calculations:

$1 /$ Includes cross-border lending and lending by foreign-owned local affiliates in each country. 
Figure 14. Three-Month Money Market Spreads

(In basis points)

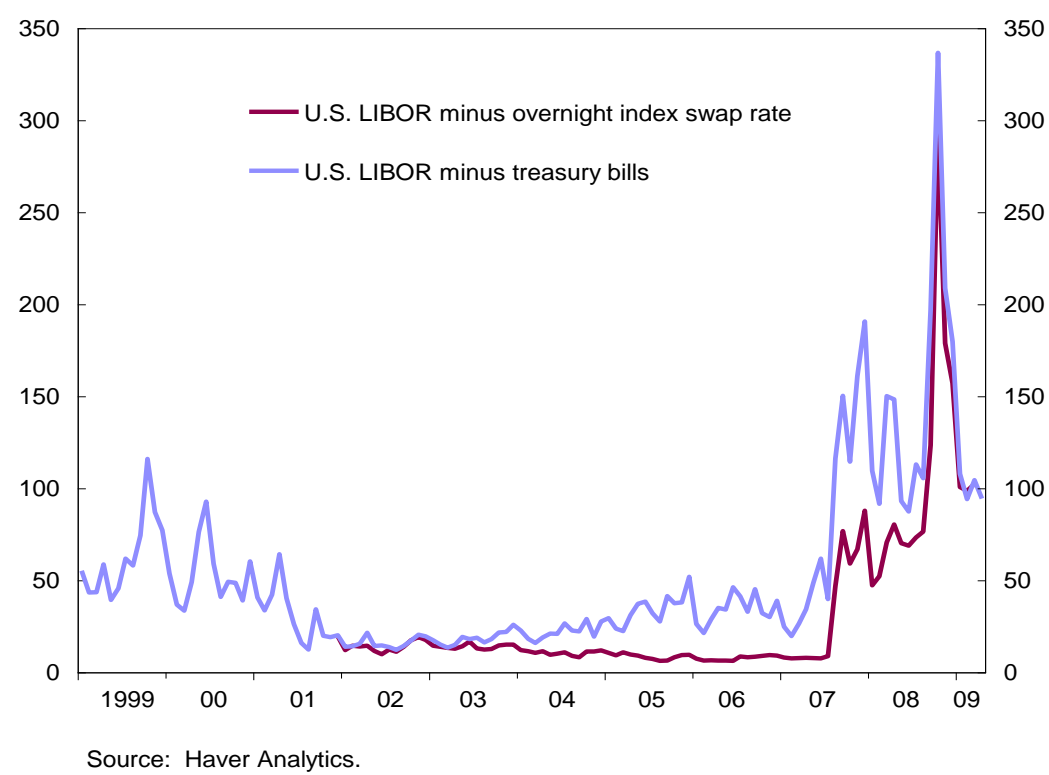

Figure 15. Financial Stress of Global Banks in Advanced Countries (Market indicator of banks' expected default frequency; median within countries)
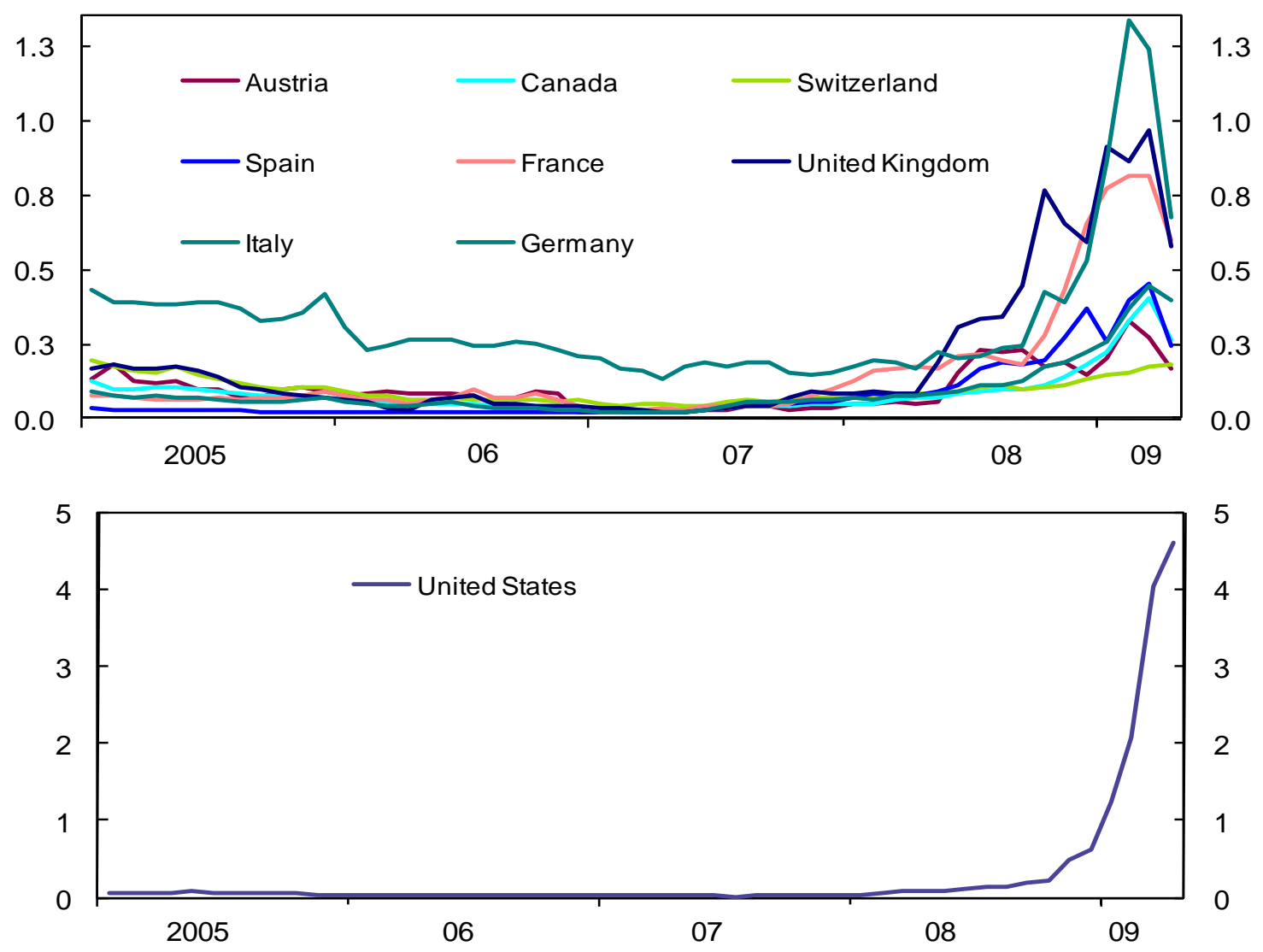

Sources: Moody's KMV; and authors' calculations. 
Figure 16. Reported Tightening in U.S. Banks' Lending Standards 1/ (Net percentage of senior loan officers tightening lending standards)

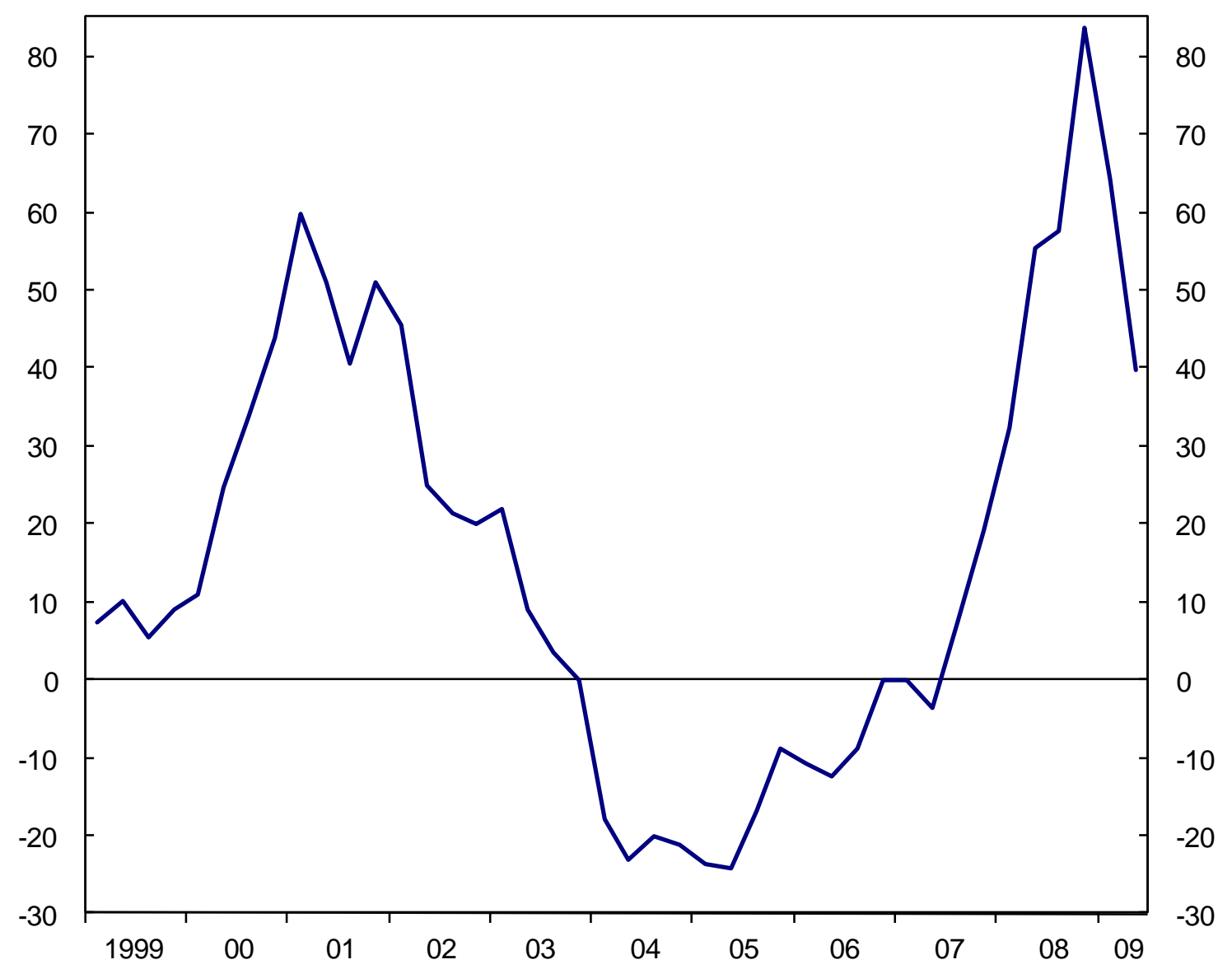

Source: Board of Governors of the Federal Reserve System, Senior Loan Officer Opinion Survey.

$1 /$ The net percentage of tightening is the percentage of senior loan officers who reported tightening minus the percentage of officers who reported easing in credit standards. Higher numbers imply tightening credit standards. 


\section{References}

Adler, Gustavo, and Eugenio Cerutti, 2009, Emerging Market Countries' Vulnerability to International Banks' Distress" (unpublished; Washington: International Monetary Fund).

Arvai, Zsofia, Karl Driessen, and Inci Otker-Robe, 2009, Regional Financial Interlinkages and Financial Contagion Within Europe," IMF Working Paper No. 09/6 (Washington: International Monetary Fund).

Calvo, Sara, and Carmen Reinhart, 1996, —Caital Flows to Latin America: Is There Evidence of Contagion Effects?" World Bank Policy Research Working Paper No. 1619 (Washington: World Bank).

Canales-Kriljenko, Jorge Ivan, Brahima Coulibaly and Herman Kamil, 2010, A Tale of Two Regions," forthcoming in Finance \& Development (Washington: International Monetary Fund).

Caruana, Jaime, 2009, Financial Globalisation, the Crisis and Latin America", Speech presented at the XLVI Meeting of Central Bank Governors of the American Continent.

Cetorelli, N. and Linda Goldberg, 2009, Globalized Banks: Lending to Emerging Markets in the Crisis," Staff Report No. 377, Federal Reserve Bank of New York.

Cetorelli, N. and Linda Goldberg, 2010, Global Banks and International Shock Transmission: Evidence from the Crisis," forthcoming IMF Economic Review.

Čihák, Martin, and Petya Koeva Brooks, 2009, From Subprime Loans to Subprime Growth? Evidence for the Euro Area," IMF Working Paper 09/69 (Washington: International Monetary Fund).

Claessens, Stijn, Asli Demirgüç-Kunt, and Harry Huizinga, 2001, How Does Foreign Entry Affect Domestic Banking Markets?” Journal of Banking and Finance, Vol. 25, pp. 891-911.

Claessens, Stijn, and Neeltje van Horen, 2008, Eocation Decisions of Foreign Banks and Institutional Competitive Advantage." Available via the Internet: http://ssrn.com/abstract $=904332$

Claessens, Stijn, Giovanni Dell‘Ariccia, Deniz Igan, and Luc Laeven, 2010, "Cross-Country Experiences and Policy Implications from the Global Financial Crisis", Economic Policy, Vol. 25, Issue 62, pp. 267-293. 
De Haas, Ralph and Iman Lelyveld, 2009, Internal Capital Markets and Lending by Multinational Bank Subsidiaries," Journal of Financial Intermediation (forthcoming).

Galindo, Arturo, Alejandro Micco, and Andrew Powell, 2004, Eoyal Lenders or Fickle Financiers: Foreign Banks in Latin America," UTDT business school working paper (Buenos Aires: Universidad Torcuato Di Tella).

Galindo, Arturo, Alejandro Izquierdo, and Liliana Rojas-Suarez, 2010, "Financial Integration and Foreign Banks in Latin America: How Do They Impact the Transmission of External Financial Shocks?," RES Working Papers 4651, Inter-American Development Bank, Research Department.

Garcia-Herrero, Alicia, and Maria Soledad Martinez Peria, 2007, The Mix of International Banks' Foreign Claims: Determinants and Implications," Journal of Banking and Finance, Vol. 31, pp. 1613-31.

Goldberg, Linda, 2001, When Is U.S. Bank Lending to Emerging Markets Volatile?” NBER Working Paper No. 8209 (Cambridge, Massachusetts: National Bureau of Economic Research).

Goldberg, Linda S., 2009, Understanding Banking Sector Globalization," Staff Papers, International Monetary Fund, Vol. 56, No. 1, pp. 171-97. http://www.palgravejournals.com/v56/n1/pdf200831a.pdf

Herrmann, Sabine and Dubravko Mihaljek, 2009, The Determinants of Cross-Border Bank Flows to Emerging Markets - New Empirical Evidence on the Spread of Financial Crises", (unpublished, Basel: Bank for International Settlements).

International Monetary Fund, 2009a, Will International Banks Transmit the Global Credit Crunch to Latin American and Caribbean Countries?" in Regional Economic Outlook: Western Hemisphere, April 2009 (Washington: International Monetary Fund).

International Monetary Fund, 2009b, Initial Lessons from the Crisis," Public Information Notice 09/30. Available via the Internet:www.imf.org/external/np/sec/pn/2009/pn0930.htm.

Jara, Alejandro and Camilo E. Tovar, 2008, Monetary and Financial Stability Implications of Capital Flows in Latin America and the Caribbean," BIS Papers No. 43 (Basel: Bank for International Settlements).

Maechler, Andrea M., and Li L. Ong, 2009, Foreign Banks in the CESE Countries: In for a Penny, in for a Pound?" IMF Working Paper 09/54 (Washington: International Monetary Fund). 
Martinez Peria, Maria Soledad, Andrew Powell, and Ivanna Vladkova-Hollar, 2005, Banking on Foreigners: The Behavior of International Bank Claims on Latin America, 1985-2000," Staff Papers, International Monetary Fund, Vol. 52, No. 3.

McGuire, Patrick, and Philip Wooldridge, 2005, The BIS consolidated banking statistics: structure, uses and recent enhancements," BIS Quarterly Review (Basel: Bank for International Settlements).

McGuire, Patrick, and Nikola Tarashev, 2008, Bank Health and Lending to Emerging Markets," BIS Quarterly Review (Basel: Bank for International Settlements, December).

McGuire, Patrick, and Goetz von Peter, 2009, The US Dollar Shortage in Global Banking," Bank for International Settlements Quarterly Review, pp. 47-63. http://www.bis.org/publ/qtrpdf/r_qt0903f.htm

Moreno, Ramon and Agustin Villar, 2005, The Increased Role of Foreign Bank Entry in Emerging Markets," in Globalisation and Monetary Policy in Emerging Markets. BIS Papers No. 23 (Basel: Bank for International Settlements).

Papaioannou, Elias, 2009, What Drives International Bank Flows? Politics, Institutions and other Determinants," Journal of Development Economics 88(2), pp. 269-281.

Peek, Joe and Eric Rosengren, 2000, Implications of the Globalization of the Banking Sector: The Latin American Experience", New England Economic Review, September/October, pp. 45-63.

Porzecanski, Arturo, 2009, Eatin America: The Missing Financial Crisis,” ECLAC Working Paper (Washington: Economic Commission for Latin American and the Caribbean).

Pozzolo, Alberto Franco, 2008, "Bank Cross-Border Merger and Acquisitions (Causes, Consequences and Recent Trends)," Economics \& Statistics Discussion Papers esdp08048, University of Molise, Dept. SEGeS.

Raddatz, Claudio, 2009, When the Rivers Run Dry: Liquidity and the Use of Wholesale Funds in the Transmission of the U.S. Subprime Crisis", (unpublished; Washington: World Bank).

Van Rijckeghem, Caroline, and Beatrice Weder, 2000, Spillovers through Banking Centers: A Panel Data Analysis,” IMF Working Paper 00/88 (Washington: International Monetary Fund).

World Bank, 2008, The Changing Role of International Banking in Development Finance," in Global Development Finance 2008 (Washington: World Bank). 
J. Zettelmeyer, Piroska Nagy and Stephen Jeffrey, forthcoming 2010, Addressing Private Sector Currency Mismatches in Emerging Europe”, EBRD Working Paper, EBRD, London. 